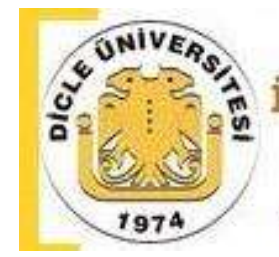

Yıl / Year: 2021

Araştırma Makalesi
Cilt / Volume: $11 \quad$ Sayı / Issue: 21

Gönderim Tarihi: 16.04.2021
DICLE ÜNIVERSITESI

E-ISSN: 2587-0106ISSN: $1309-4602$

DICLE UNIVERSITY

JOURNAL OF ECONOMICS AND ADMINISTRATIVE SCIENCES

Sayfalar / Pages: 168-205

Kabul Tarihi: 04.05.2021

\title{
POST-FORDİZM, ESNEKLİK VE EPDK
}

\section{Mehmet SARITÜRK ${ }^{1}$}

\section{$\ddot{O} z$}

Kapitalist ekonomik sistem, yapısından kaynaklanan krizler ortaya çıkarmaktadır. Üretimin emeğe ödenmeyen kısmını artı-değere, artı-değeri kâra dönüştürmekte kâr ise sermayeye dönüştürülmektedir. Ekonomik, siyasal, idarî ve kültürel yapının işleyişini bu özellik oluşturmaktadır. Yapısal krizler ortaya çıktığında yeni birikim rejimleri ile krizler aşılmaktadır.

1929 ekonomik krizi talep yetersizliğinden kaynaklanmıştır. Bu kriz yeni bir birikim rejimi ile aşılmıştır. Fordist birikim rejimi döneminde talep yetersizliğini aşmak için topluma kaynak aktarımı yapılmış ve ekonomik sistemin devamı sağlanmıştır. Yapısal krizler 1960'lı yılların ortalarından itibaren kâr hadlerinin yeniden düşmesi ile birlikte yeniden ortaya çıkmıştır. Bu dönemde yapısal krizlerin ortadan kaldırılması için sistem, yeni bir birikim rejimi dönemine girmiş, fordist dönem uygulamaları ortadan kaldırılmış arz temelli bir ekonomiye geçilmiş, talep artırıcı uygulamalara son verilmiştir. Yeni dönem, neo-liberal dönem ya da farklı bir analiz çerçevesi içerisinde post-fordist dönem olarak adlandırılmış ve bu dönemde esnekliğe dayalı yeni düzenlemeler gerçekleştirilmiş, toplam kalite yönetimi felsefesine uygun olarak devlet yeniden yapılandırılmış, devletin yapısı parçacıl hale getirilmiş, bağımsız idarî otoriteler (BİO) vb. yeni kurumlar oluşturulmuş ve esneklik uygulamaları yaygınlaştııılmıştır. Esneklik kavramı, devletin yeni örgütlenme anlayışının anlaşılması bakımından anahtar kavramlardandır.

Anahtar Kelimeler: BİO, Esneklik, Fordizm, Postfordizm, EPDK.

Jel Kodları: H10, H11, H83, L00, L5, P11, P16, P35.

${ }^{1}$ Dr. Öğr. Üyesi, Adıyaman Üniversitesi İİBF Kamu Yönetimi Bölümü, E-posta: mehmetsariturk@ hotmail.com, ORCID: 0000-0002-9054-8170.

\section{Atıf/Citation}

Sarı̈ürk, M. (2021), "Post-Fordizm, Esneklik ve EPDK”, Dicle Üniversitesi İktisadi ve İdari Bilimler Fakültesi Dergisi, 11(21), s.168-205. 


\title{
POST-FORDISM, FLEBILITY AND EPDK
}

\begin{abstract}
The capitalist economic system creates crises arising from its structure. The part of production that is not paid for labor is transformed into surplus value, surplus value into profit, profit is transformed into capital. This characteristic constitutes the functioning of the economic, political, administrative and cultural structure. When structural crises occur, crises are overcome with new accumulation regimes.

The economic crisis of 1929 stemmed from the lack of demand. This crisis has been overcome by a new accumulation regime. During the Fordist accumulation regime, resources were transferred to society to overcome the lack of demand and the economic system was continued. Structural crises re-emerged from the mid-1960s with the decline of profit rates again. In order to eliminate structural crises in this period, the system entered a new accumulation regime period, fordist period practices were eliminated, a supply-based economy was initiated, and demand-increasing practices were terminated. The new period was named as the neo-liberal period or the post-fordist period within a different analysis framework, and new arrangements based on flexibility were realized in this period, the state was restructured as required the philosophy of total quality management, the structure of the state was fragmented, independent administrative authorities (IRAs), etc. new institutions were created and flexibility applications are widespread. Flexibility is one of the basic thought in understanding the new organization of the state.
\end{abstract}

Key Words: IRAs, Flexibility, Fordism, Postfordism, EPDK.

Jel Codes: H10, H11, H83, L00, L5, P11, P16, P35.

\section{GíRIŞ}

Kamu yönetiminin yapısı ve işleyişi post-fordist dönemde ekonomik sistemin ihtiyacını karşılamak için yeniden oluşturulmuştur. Düzenlenmenin ideolojisini tesis eden neoliberalizm yaklaşımı 1930'lu yılların ortasından başlayarak şekillendirilmiştir. Neo-liberalizm girift usullerle ve çok sayıda yöntem ve araç kullanılarak İkinci Cihan Harbi'nden 1970'li yılların ortasına kadar geçen zamanda yaygınlaştırılmıştır. 1970'lerden sonra ise neoliberalizmi destekleyici ekonomik, siyasal, bürokratik ve kültürel teoriler oluşturulmuş ve laboratuvar olarak kullanılan devletlerde uygulaması gerçekleştirildikten sonra önce İngiltere ve $A B D$ ve sonra diğer anglo-sakson protestan ülkelerde ve daha sonra da diğer ülkelerde yeni birikim rejimi olarak hayat geçirilmiştir.

Yeni Kamu Yönetimi Yaklaşımının (YKYY) özellikle yeni kamu işletmeciliği düşüncesinin gereği olarak özel sektör yönetim anlayışı ve uygulamalarının kamu yönetiminde de verimlilik ve etkinlikle sonuçlanacağı kabul edilmiştir. Neo-liberalizm temel yaklaşım olarak kabul edilerek, devletin ekonomik alanda etkin olmadığ 1 , bu durumun sonucu olarak verimsizliği ve kötülüğü nedeniyle topluma zarar verdiği iddiasına yeni regülasyonlar ve özelleştirmeler aracılığı ile devletin ekonomik gücü ve alanı sınırlandırılmıştır. Yeni birikim rejiminin yerleştirilebilmesi için önce kuralsızlaştırmalar daha sonra da düzenlemeler 
gerçekleştirilmiştir. Post-fordist dönemde devlet, ekonomik sistemin yeni ihtiyacına uygun olarak tekrar şekillendirilmiştir.

Devletin post-fordist yaklaşıma uygun olarak her sektörde alanının daraltılması ve örgütlenme şeklinin yeniden oluşturulması ile devletin bürokratik örgütlenmesi, esneklik anlayışına uygun olarak yeniden oluşturulmuştur. Kamu bürokrasisi, özel sektörün örgütlenme ve çalışma anlayışına uygun olarak yeniden örgütlendirilmişstir. Bağımsız idari otoriteler (BİO’lar), postfordist dönem kamu yönetimi örgütlerinin model örneklerindendir. Düzenleme için oluşturulan kurumlar olan BİO'lar, örgütlenmeleri esneklik anlayışına uygun olarak oluşturulmuş, fordist dönem bürokrasisine göre çok daha güçlü yetki ve sorumluluklara sahip olmuş, yönetişim anlayışını temel alan roller yüklenmiş ve siyasal yapı weberyen bürokrasiden çok farklı özellikte bağlar kurmuş ve bu özellikleri bakımından politik ve bürokratik yapıda yeniden oluşturulmuş ve ağırlıklı bir konuma getirilmiştir.

Önemli ve çok boyutlu bir alan olan enerji alanı, BİO’ların oluşturulması ve yönetmesi için ekonomik değeri ve örgütlenmesi açısından uygun ve ilk düzenlenen sektörlerdendir. Mal ve hizmet üretiminin ve diğer ekonomik faaliyetlerin yürütülmesi hayatın her alanı için önemlidir. Sosyal devlet döneminde, başka bir ifadeyle fordist dönemde, umumiyetle enerji sektörü doğal tekel özelliğindedir ve ağ yapılı örgütlenme ile faaliyetlerini yürütmektedir. Enerjinin ekonomik potansiyeli ve değeri önemlidir. Enerji piyasasında, fordist dönemde elektrik enerjisinin örgütlenmesi dikey bütünleşik örgütsel yapıdadır ve post-fordist dönemde yapısı parçalanmış ve ağ yapılı hale gelmiştir. BİO’lar da yaygın olarak ortaya çıktıkları ABD’de, ağ yapılı ve eyaletler arasında yaygınlaşmış hizmetleri yürütebilmek için oluşturulmuş ve yeni birikim rejimi döneminde de ağ yapılı ve eyaletler arası faaliyetlerin bulunduğu alanlarda varlığını sürdürmüştür.

Enerji alanı, dikey olarak birleşmiş yapıda olan örgütlenmesinin parçalanma kolaylığı ve piyasa değeri kazandırılarak özelleştirilebilmesinden dolayı, stratejik özelliği de bulunduğu için öncelikli olarak özelleştirme ve regülasyonların gerçekleştirildiği alan olmuştur. Uluslararası kuruluşlar, enerji sektörünün stratejik özelliği nedeniyle, özelleştirilmesi ve düzenlenmesi için özellikle çalışmalar yapmışlardır.

$\mathrm{Bu}$ çalışmanın amacı, neo-liberal ideoloji ve post-fordist birikim rejimi uygulamalarının kamu yönetimi alanındaki esnekliği BİO’lar ve çalışmanın örneği olan Enerji Piyasası Düzenleme Kurumu (EPDK) araştırılarak değerlendirmektir. Çalışmada başlangıçta esnekliğin 
oluşmasının ve gelişiminin altyapısal analizini fordist ve post-fordist aşamada betimsel yöntem ile yapmak, daha sonraki aşamalarda ise BİO'ları ve BİO örneği olarak EPDK'yı esneklik açısından incelemektir. Çalışmaların amaçları arasında ekonomi politik anlayışa dayanarak kapitalist ekonominin devlet ile ilişkisini anlamaya çalışmak, yöntemi ise ikincil kaynak araştırması ile betimsel olarak konuyu açıklamaya çalışmaktır. Bağımsız idarî otoriteler, post-fordist dönemde yaygınlaştırılan kurumlardandır ve bu yeni dönemi anlamayı kolaylaştıracak tipik örneklerdendir. $\mathrm{Bu}$ nedenle bağımsız idarî otoriteleri anlamak postfordist dönem kamu yönetimini analiz etmeyi kolaylaştıracaktır.

\section{KAMU YÖNETIMINDE ESNEKLİĞIN ALTYAPISAL ÇÖZÜMLEMESİ}

Kapitalist toplumun ana sınıfları burjuvazi ve proletaryadır. Kapitalist üretim tarzı devam ettiği müddetçe bu iki sınıf ayrılmaz bir şekilde birbiri ile bağını sürdürür: Sermayedar sınıf, ücretli işçileri sömürerek zenginlik sağlar ve varlığını devam ettirir. Proletarya ise devamlılığını sermayedar sınıf için çalışarak devam ettirebilir. Bunun yanı sıra proletarya ve sermayedar sınıf, çıkarları çatışan ve çıkarları bakımından tamamıyla uzlaşması imkânı olmayan antagonist nitelikte yapılardır. Burjuvazi, kapitalist sistemin egemen sinıfidır. Kapitalizmin yerleşmesi, sömüren azınlık olan burjuvazi lehine sömürülen çoğunluk olan proletarya aleyhine oluşan uçurumun genişlemesine ve derinleşmesine sebep olmaktadır. Sermayedar sınıf ile proletaryanın sınıf rekabeti, kapitalist sistemin motor gücünü sağlar. (Anonim, SSCB Politik Ekonomi Ders Kitabı, 1992: 156).

Sanayi sermayesi, oluşturulması sermayenin fonksiyonu olan, artı-ürünün ya da artı-değerin ele geçirildiği, ortaya çıkma şeklidir. Bu özelliği nedeniyle, üretimin kapitalist özelliği bir mecburiyettir. Sanayi sermayesinin ortaya çıkması sermayedar sınıf ile proletarya arasındaki antagonistik sınıf konumunu ifade etmektedir. Toplumsal üretimin kontrolünü sağlama seviyesine bağlı olarak, teknik ve toplumsal olarak emek sürecinin oluşumu kökten yeniden yapılanır ve buna bağlı olarak toplumun ekonomik olarak tarihsel yapısı ve modeli de yeniden oluşur (Marx, 1997: 56). Üretimin toplumsal biçiminin tarihsel süreç içerisinde nasıl olduğundan bağımsız olarak, üretim araçları ve emekçiler, daima onun bileşenleri olmuştur. Birbirlerinden kopmuş hale gelmeleri durumunda yapıyı oluşturan bileşenlerden birisi yalnızca potansiyel olarak bulunmaktadır. Çünkü üretimin yapılabilmesi için bunların birlikte ve diğerini tamamlayacak şekilde bulunmaları gerekmektedir. $\mathrm{Bu}$ bütünleşmenin gerçekleştirildiği kendine has şekil, toplumun çeşitli ekonomik dönemlerini diğerinden ayırmaktadır. Kapitalist dönemde, serbest çalışanın üretim araçlarından koparılması, sistemin devamı için bir hareket noktasını oluşturmaktadır. Malların şahsi ve reel kurucuları bu şekilde 
oluşturulduktan sonra, gerçekleştikleri uygulama süreci, başka bir ifade ile üretim süreci, ifade edilen nedenden dolayı sermayenin bir fonksiyonudur (Marx, 1997: 43).

Art1-değer üretmek ya da kazanç elde etme kapitalist ekonomi ve üretimin temel kanunudur ve kapitalist ekonomi artı değere dayanmaktadır. Artı-değeri, ücretli işçinin ödenmeyen emeği oluşturur, bütün sermayedar sınıfın kendi emeğiyle elde edilmeyen gelirinin ana kaynağıdır (Anonim, SSCB Politik Ekonomi Ders Kitabı, 1992: 156). Üretim ortaya çıkarıldı̆̆ında pazarlanmaktadır. Bu durum hem bir dağıtım yapısının ve ağının hem de mallara yönelik efektif talebi ve satın alacak ekonomik güce sahip olan bir grubun varlığı ile mümkün olmaktadır. Emtia, satışın bütün dönemlerinde satıcının katlandığı maliyetlerden daha fazla bir fiyattan satılmalıdır. Maliyet ile satış arasında oluşan fiyat farkı kısmı, satıcının hayatını sürdürmesi için gereken asgari gelir miktarından fazladır. Diğer bir ifade ile satışın yapılabilmesi için kâr olmalıdır. Elde eden elde edilen kârı, yatırım için kabul edilebilir bir firsat oluncaya kadar tasarruf etmekte, üretim gerçekleştirecek şekilde yatırım yaptı̆̆ zaman ise ekonomik gücünü yenileyebilmeyi ve artırmayı hedeflemektedir (Wallerstein, Tarihsel Kapitalizm, 1996; 13). Artı değer kârın kaynağı, kâr ise sermayenin kaynağıdır. Kapitalist üretimin amac1, artı-değerin sermayeye dönüşümünü sağlamaktır. Sistem en yüksek verimlilik oranıyla en fazla artı değeri sağlamayı hedeflemektedir (Zubritski vd., 1995: 17). Artı değerin artırılması, kârlılığın ve sermayenin artırılmasını sağlamaktadır. Sistem, artı-değerin artık çoğaltılamaması ve kârlılık oranlarının azalmaya başlaması ile birlikte kapitalist ekonomi krize girmektedir. Artı-değer üretimini tekrar pozitif hale getirebilmek için teknoloji geliştirerek gerekli emek zamanını azaltma ya da çalışma sürelerini artırma yoluna gitmişlerdir (Zubritski vd., 1995: 17).

Kapitalist sistemin başka bir özelliği, krizler aracılığı ile devamını sağlamasıdır. Marx, kapitalist sistemde krize yol açan faktörleri; kredi düzeninin işleyişi, yarışma şartları ve üretim hareketleri olarak ifade etmiştir. Kredi düzeninin işleyişinden anlaşılması gereken şey, pazarın kriz ya da bunalım zamanındaki finansman kurumlarının işleyiş şekli ve yapısal özellikleridir. Bu unsurların sistem içerisindeki yeri ve kendi aralarındaki münasebetleri krize sebep olmaktadır. Marx, bahsedilen unsurların faaliyetlerinde ve kendi aralarındaki bağlantılarında krizin oluşmasına neden olan ana nedenin kâr oranları olduğunu varsaymaktadır. Başka bir şekilde anlatmak gerekirse, sistemde kâr hadlerinin düşmeye başlaması krize neden olmakta ve kâr hadlerindeki azalma ve üretimin değişmesi, piyasanın 
yapısal şartları, yarışma ve finansman yapısı gibi unsurları bunalıma neden olacak şekilde etkilemektedir (Şaylan, 2003: 86).

Kapitalizmin, hayat tarzı ve bir sistem olarak devamlılığını sağlamasının ontolojik şartı, sermaye birikim sürecinin kararlı ve sürekli şekilde sürmesidir. Sermaye birikim sürecinin kararlılığı ve sürekliliği, kriz tanımının kaynağıdır. Krizler, farklı zaman ve yerlerde ve tarihsel şartlarda oluştuğu için her kriz diğerlerinden farklıdır. Farklı krizlere yol açan faktörler ve kriz ile oluşan neticeler değişmektedir ve ortaya çıktığı şartlara bağlıdır. Fakat, krizler, kendine has özellikler taşısa da temel özelliği itibariyle, sermaye birikim sürecinin yapısı ve işleyişinin istikrarının sona ermesi anlamına gelecektir. Diğer bir ifadeyle, bütün krizler ekonomik sistemde ve dolayısıyla bütünüyle sistemde birikim sürecinde istikrarın zarar görmesi, kontrolün kaybedilmeye başlanması ve istikrarsızlaşma özelliği taşımaktadır (Şaylan, 2003: 88).

Rekabet, kapitalizmde sermayenin artmasını sağlayıp, üretimi ve birikimi artırmakta fakat kâr haddi oranlarını düşürmektedir. Bu durum yapısal krizlere ve tekelleşmeye sebep olmaktadır (Marx, 1993: 111).

Kriz ve gerileme döneminde kitle tüketiminde ve satın alma gücünde azalma gerçekleşir. Ancak kapitalizmde tüketimdeki düşüş, üretim yetersizliğinin ya da azlığının bir sonucu değildir (prekapitalist dönemde üretimin düşmesi, yeterli olmaması nedenine dayanabilmektedir.). Kapitalist dönemde üretimin azalması, kitlelerin tüketebileceğinden daha fazla üretimin yapılması sonucunda ortaya çıkmaktadır. Kapitalizmde tüketim kapasitesinin üzerinde gerçekleştirilen üretim, işsizliğe, rasyonalizasyona, iflaslara, fakirleşmeye ve tüketimin azalmasına neden olmaktadır. İşleyiş bu durumları oluşturuyor olsa bile fonksiyoneldir. Ekonomik kriz ya da daralma her şeyden bağımsız ve tam anlamıyla kontrol dışı bir kaza özelliği taşımaz. Bilakis üreticiler arası rekabete ve özel teşebbüse dayalı bir sistemde kâr haddini yeniden istikrara kavuşturmanın ve eski haline getirmenin bir aracıdır (Gouverneuer, 1997: 243).

Ekonomik sistem içindeki bu dinamik faktör, üretim araç ve tekniklerindeki değişimdir. Çalışanların verimliliği maliyeti artırmadan artırılabilirse sermaye temerküzü sağlanabilmektedir. Bu yaklaşım içerisinde maliyeti düşürmek için yeni demirbaş ve eşya yeni teknikler ve yeni üretim teknikleri geliştirmek hedeflenmektedir. Bu çabaların amacı, kendi başına üretimi artırmak ya da maliyeti azaltmak değildir, nihai hedef, kârını artırmanın yollarını bulmaktır (Eaton, 1996: 187). 


\subsection{Postfordizm ve Bağımsız İdari Otoriteler}

1929 Yılı'nda ABD'de borsanın çökmesi sonucunda kapitalist sistemde kriz ortaya çıkmış, bir dönem sona ererek başka bir döneme geçilmiştir. Bu durum, derin ekonomik, siyasal, sosyal dönüşümlerin kaynağı olmuştur (Sarıtürk, 2009: 7).

1929 ekonomik kriziyle birlikte sistemin devamını sağlamak için, New Deal uygulamaları dönemine geçilmiştir. $\mathrm{Bu}$ uygulamaların temel varsayımı; piyasanın dışarıdan müdahale olmaz ise dengeye ulaşamayacağıdır. Piyasa, devletin müdahalesi ile dengeye ulaşabilmektedir. Sistemin sürekliliğini sağlayabilmek için, devlet, refahın ülke ölçeğinde dağıtımını yapma faaliyetini oluşturmuştur. Bu anlayış ve anlayışa uygun çalışmalar, fordist dönemi ya da refah devleti/sosyal devlet dönemini oluşturmuştur. Keynes'in düşünceleri, 1929 bunalımını aşmada iktisat teorisi açısından belirleyici bir etki oluşturmuştur. Kesinliğine ve doğruluğuna inanılan klasik iktisat teorisi yıkılmış, yerini Keynes'in düşünceleri ikame edilmeye çalışılmıştır (Erdoğan ve Ak, 2003: 3). Keynes'in müdahaleci devlet yaklaşımı, II. Dünya Harbi'nin sona ermesinden sonra uygulanmış ve 1970’li yılların ortalarına kadar dönemin belirleyici yaklaşımı olmuştur. Keynezyen dönem hem merkezdeki hem de çevredeki ülkelerde, ilhamını merkez ülkelerde keynezyen yaklaşımdan, çevredeki ülkelerde ise kalkınma iktisadı anlayışından alan devletin çok boyutlu ve yoğun müdahalelerinden oluşmuştur. Diğer bir ifadeyle devlet-sermaye, siyaset-piyasa ikilerinde birinci alternatifler sürekli ön plana çekilmiştir. Devlet, kapitalist birikim yapısını ve işleyişini devamlı olarak kontrol altına almakla kalmamış, üstelik sevk ve idare etmiş ekonomik işleyişten zararlı çıkanları, kapitalizm lehine gözetmeye çalışmış ve bölüşüm dengesizliğini ve işsizliği (Aydın, 1999: 3) kapitalizmin devamı gerektirdiği için azaltmaya çalışmıştır.

Keynezyen iktisadi yaklaşım, talep yanlı ekonomi politikalarıyla satın alma gücünün artırılarak toplam talebin artırılması ile tam istihdamın gerçekleştirebileceğini iddia etmektedir. Tam istihdamın gerçekleşebilmesi için uygulanan en güçlü yöntem vergilere uygulanan kesintidir. Bu kesinti, iktisadi alanda çarpan etkisi oluşturarak çalışanlara daha yüksek miktarda para aktarılmasının işe yarar yöntemlerindendir ve satın alma güçlerini artıracaktır. Bu durumda çalışanlar, daha fazla para sahibi olacakları için efektif talepleri yükseltecek ve talebin yükselmesi de istihdam potansiyelinin artmasına neden olacağından ekonomik sistemin devamını sağlayacaktır. Bu tip iktisat politikaları, fordist üretim örgütlerini ortaya çıkarmıştır. Fordist üretim şekli, örgütsel ve teknolojik özellikleri 
bakımından kütlesel-standart ürünler oluşturmak için geliştirilmiş, umumiyetle vasıfsız ya da yarı vasıflı işgücünün taylorist usullerle yönetildiği, üretimde montaj/üretim hattı usulüne göre çalışan kütle üretimi yapan örgütlerde gerçekleştirilmekteydi (Phillips ve Ilcan, 2003: 438).

Sosyal devlet döneminde liberal, katılımcı ve çoğulcu demokrasiler geliştirilmiş ve korporatist bir düzen oluşturulmaya başlanmıştır. Korporatizmde işveren ve işçinin siyasal sistemin ve devletin içerisinde bulunduğu, baskı ve çıkar gruplarının siyasal sistemde güç ve etki sahibi olması durumu tesis edilmiştir. Korporatizmin en belirgin özelliği, siyasal süreçte liberal çoğulcu ya da çoğunlukçu söyleme uygun olarak gelirin yeniden dağıtımının gerçekleştiği poliarşik yani çoğulcu ya da çoğunlukçu liberal yapıyı temsil etmesidir. Gelirin yeniden bölüşümünün ekonomi üzerine etkileri, ekonomide önce talebin bileşenlerini ve yapısını değiştirmiş, talebin bileşenleri ve yapısının değişmesi ise arz yapısını yani üretimi, üretimin bileşenleri ve yapısında gerçekleşen değişim ise üretim faktör fiyatlarının yeniden şekillenmesini sağlamış, bu durum ise firmaların marjinal teknik ikame oranlarının yeniden oluşturmuştur. Faktör fiyatlarının değişimi ile birlikte şirketlerin teknik ikame oranlarının yeniden oluşması ise gelir ve kârın yeni şartlarda yeniden yeni bileşenleri ile ortaya çıkması ve paylaşılmasına neden olmuştur. Üretim-bölüşüm etkileşimi bir işleyişin sonucunda ortaya çıkmakta ve zamana yayılarak gerçekleşmektedir. Bu açıdan değerlendirildiğinde korporatizm yaklaşımıyla cisimleşen refah devleti tipi, üretimin yanı sıra bölüşüm aşamasının da politikleştiği bir işleyişi ifade etmektedir (Akyıldız, 2005: 31).

Kapitalist sistemde tüketim modelleri, emek süreci, teknoloji biçimleri ve toplumsal yap1 ve bütünüyle örgütler arasında bütünlük ve sinerjiye neden olan bir bağ ve işleyiş bulunmaktadır. Her kriz döneminden çıkmak için oluşturulan bu sinerji dönemlerine "birikim rejimi" denmektedir. Birikim rejimi, tüketim, üretim ve idarî denetim arasındaki kendine has regülasyonların belirlediği değişik dönemlere ayrılmaktadır. Birikim rejimi, üretim ve tüketim arasındaki nispi olarak düzenli ve istikrarlı, uluslararası ekonomi seviyesinde belirlenen, yeniden üretilebilir bir bağ ve ilişkidir. Devamlılığını sağlamak için yapısal ve sürekliliği olan düzenlemeler gerekmektedir. Bu açıdan halen devam eden birikim rejimi ve sosyal ilişkilere uygun olarak ve bunlarla ve kendi içinde ahenk içinde olacak kurumsal ilişkiler, kurallar ve şekiller bütünü "düzenleme tarzı" olarak ifade edilmektedir. Düzenleme tarzı veya şekli kurumsal olarak ahenge (uzlaşımlar, kanunlar, vs.) bunun sonucu olarak da kapitalist yeniden üretimin devamını sağlayan girift kültürel yapılar, alışkanlıklar ve normları imlemektedir. Regülasyon şekli, kurucu sosyal yapı ilişkilerden hareket ederek bunlardan bir sistem 
oluşturan düzenli ya da düzensiz kurallar bütününü oluşturmaktadır. Bu nedenle, kanunlar, kamu siyasaları, politik anlayış, endüstriyel özellikler, uygulamalar, yönetim anlayışları ve yaklaşımları, karşı1ıklı dayanışma ve anlaşma şartları, tüketim kültürü ve sosyal beklentiler düzenleme tarzının yapısını oluşturan bileşenlerdendir (Balkız, 2002: 89).

Kapitalist sistemde devletin rolü, sistemin kendisi için hayatidir. Fakat devletin işlevleri içerisinde potansiyel olarak bir gerilim ve zıtlık bulunmaktadır. Kapitalist, liberal toplumsal yapılara has politik kurumlar ve düzenlemeler, bahsi geçen zıtlı̆̆ yapısı gereği keskinleştirmektedir. Kapitalist sistemde bölüşüm konusunda ortaya çıkan çekişme, politik bir olguya dönüşmektedir. Bütün bu özellikler, liberal ideolojinin teorik tahminlerinin tersine, sistemden kaynaklanan krizlerin kaçınılmaz olduğunu göstermektedir. Bunun nedeni, birikim sürecinin, liberal teoride kurgulandığı gibi kararlı ve sürekli bir şekilde devam etmemektedir. Birikim sürecinin, kesintiye uğraması ve istikrarsızlaşması seklinde görünür hale gelen kriz, zamanla sosyal bağları, davranış kalıplarını ve sosyal ilişkileri de etkilemekte; başka bir ifade ile birikim sürecinde oluşan toplam hayat şeklinin bunalımına yol açabilmektedir. Kapitalist sistemin bunalımı ve krizleri ekonomik, siyasî ve kültürel alanları ve hayatın bütününü içeren bir sistemin yeniden düzenleme çalışması ile aşılabilmektedir (Şaylan, 2003: 89). Bu bakımdan incelendiğinde, sosyal devlet, üretim alanında esneklikle ilgili mikro ekonomik uygulamaları sınırlandırmaktadır. Devlet, işgücü piyasalarını ve ücret ilişkisini yönlendirmekte ve efektif talebi canlandırarak serbest piyasanın devrevî krizlerini engelleyerek arz ve talebi dengeleyebilmektedir. Ayrıca, devlet bu yöntem ile artan kâr oranlarını güvence altına almaya çalışmış ve kârı yatırıma yönlendirmiştir. Talebin artması, ücretler, verimlilik, kârlar ve yatırımlar silsilesinin oluşturduğu fordist dönem büyüme şeklinde devlet, yönlendirdiği sermaye ve tüketim malları üreten sanayisinin sermaye ile bütünleştirilmesi ve emek-sermaye arasındaki ücret yapısını ve işleyişini yönetmesi yöntemiyle kurucu bir rol oynamaktadır (http://www.petrol-is.org.tr).

Minimal devlet anlayışına dayanan dönemde kapitalizm, refah devleti/sosyal devlet uygulaması ile birikim rejimi krizi aşılabilmiş, bunun yanı sıra; Marksizm’in politik ve toplumsal eleştirisinin kapitalist sistem üzerindeki muhtemel olumsuz sonuçlarını etkisiz hale getirebilmek için düzenleme ve ekonomik gelişme demokratikleşme ile tamamlanmaya çalışılmıştır. Marksizm'in kapitalizme yönelik eleştiri ve değerlendirmeleri, sistemin kendini yenileme çabalarının iki ana faktörü olan demokratikleşme çabaları ve sosyal/refah devleti 
uygulamalarının yanı sıra teorisinin oluşturulmasında da belirleyici bir tesire sahiptir (Şaylan, 2003: 103).

Fordizmin temel faktörleri, keynezyen refah devleti yaklaşımının nispeten kapalı şekil ve fonksiyonudur. Fordizmde devlet, pazar politikalarını, işgücü piyasasını, toplam talebi ve ücret ilişkilerini yönlendirerek yönetmektedir. Bu yönetimi, talep ve arz arasında ahenk oluşturarak sürdürmeyi hedeflemektedir. Bunun yanı sıra ekonominin dalgalanmalarını denetim altına alarak, büyümenin istikrarlı ve güvenli şekilde oluşmasını amaçlamaktadır (Jessop, 2002: 462).

Fordist dönemde devlet, bunların yanı sıra alt yapı yatırımlarını da yaparak ve kitle tüketimini teşvik edici depolama ve nakliye politikaları oluşturmaktadır. Fordist büyüme modelinin uygulandığı dönemde devlet, örgütlenmiş sermaye ve emek çıkarları arasında sosyal refah ve tam istihdam politikaları aracılığı ile krizi aşmaya çalışmıştır. 1960'tan sonra başlayarak 1970’li yılların ortalarına kadar fordist yaklaşımın yaygınlaşması ve yerleşmesi refah devleti politikası uygulamalarının birçoğunun ve bunların sonucu olarak oluşan üretimdeki artışı, bürokratizmi ve şehirleşmeyi yaygınlaştırmıştır (Jessop, 2002: 457).

Fordist birikim rejimi döneminin krize girmesinde ve yeni bir döneme geçilmesinde çok sayıda unsur etkili olmuştur. $\mathrm{Bu}$ unsurlar arasında belirleyici olan, 1973'teki petrol fiyatlarındaki yüksek oranlı artış ve devamında ortaya çıkan krizdir. Petrol fiyatlarının yüksek oranlarda artması, girdi maliyetlerini artırarak ekonomik büyüme oranlarını düşmesine neden olmuş, Fordist birikim rejimi döneminde sınırlarına ulaşan kitle üretimi sebebiyle piyasaların bazı mallara doymuş olması ve talebin değişerek çeşitlenmeye başlamasıdır (Balkız, 2002: 67).

Fordizmin krize girmesinden sonra, 1980’lerde, krizi aşmak için yeni bir düzenleme biçimi ve birikim rejiminin ilk somut uygulamaları oluşturulmaya başlanmış, 1990'lı yılların ilk yarısı ile birlikte bütünüyle yeni bir düzenleme şekli ve birikim rejimine geçilmiştir. Post-fordist birikim rejimi, kendisinden önce kapitalizmin krizini çözmek için geliştirilen fordist birikim rejiminin bunalımını aşmak için oluşturulan yeni yaklaşımdır. Post-fordist birikim rejimi ile birlikte sosyal yapı yeni ihtiyaca uygun olarak yeniden şekillendirilmiş, burjuva sınıfı, fordist birikim rejimi döneminde devamlılığını sağlayan ama yeni dönemde devamlılığını olumsuz etkileyen ve sınırlayan düzenlemeleri sonlandırmış, küresel ölçekte hareket imkânı ve akışkanlık oluşturmuş, üretim aşamasından itibaren bütün sosyal yapılarda esas paradigma haline getirdiği esnekliği yerleştirmiştir (Aslan, 2005: 98). Fordist üretim tarzının iyi örgütlenmiş sendikacılığı, şirketlere yüksek devlet müdahalesi, standartlaştırılmış iş 
sözleşmeleri, ulusal tekeller ve iş dünyasına bürokratik müdahale uygulamalarının yanı sıra özelleştirilmiş ve melez, devlet / özel şirketler uygulamaları gerçekleştirildiğini küresel pazarlardaki değişikliklere hız ve verimlilikle cevap veren yeni esnek ağlar oluştuğunu belirtmektedir (Willis, King, 2011: 23). Post-fordist dönemde, BİO modeli, çeşitli politika alanlarında, düzenleyici konularla ilgilenmek için dünyada ve Avrupa'da standart kurumsal seçim haline gelmiş, kamu hizmetleri, çevre ve finansal piyasalar gibi çeşitli politika alanlarında bütün dünyada yaygınlaşmıştır (Ennser-Jedenastik, 2016: 508).

Post-fordist birikim rejimi, karakteristik birtakım özellikler taşımaktadır (Esser ve Hirsch, 1995: 76):

1) Post-fordist birikim rejiminde, üretimin gerçekleştirilmesi ve çalışanların teşkilatlanması yeni geliştirilen haberleşme ve bilgi teknolojilerine göre oluşturulmaktadır. Bahsedilen özellik, üretimin büyük ölçekli olmasının nihayete ermesi olarak değerlendirilmemelidir. Teknolojik açıdan yeni sistem, örgütsel yapıya ve iş örgütlenmesine etkisi nedeniyle işgücünün umumi ve müşterek hareketi gerçekleştirmelerini engellemektedir. Çok boyutlu bir toplumsal marijinalizasyon işleyişi geliştirilmekte, ücretler ile işin birbirleri ile bağlantılı olarak etkili, kuvvetli ve etkili bir parçalanma oluşturulmaktadır.

2) Bilgi ve iletişim teknolojileri hizmet sektörünü büyütmüş, yaygınlaştırmış ve güçlendirilmiştir. Hizmet sektöründeki bu değişimler çalışanların toplumsal yapılarını radikal bir şekilde değiştirmiştir. Bu durumun yanı sıra bilgi üretimi ve iletişimin artmasına neden olmuşlardır. Post-fordist dönemde bilgi ve iletişim teknolojilerindeki gelişim ve yeni birikim rejimi, bireyselleşme ve bireyselleşmenin sosyal yapılara yönelik tesirini güçlendirmişlerdir. Bölgesel ekonomik, siyasi ve idari yapıların farklılaşmasına ve eski ve yeni sanayi bölgelerinin ve yeni mahalli hizmet alanlarının oluşturmuşlardır. Hizmet alanında yeni sektörlerin oluşturulması toplumsal alanda da yoğunlaşmış "küresel şehirler"i ortaya çıkarmıştır.

3) Yeni kapitalizasyon atağı, hizmet alanlarının endüstrileştirilmesine, tarımsal endüstrileşmenin kökleştirilmesine ve çok boyutlu hale gelmesine, güçleri artan örgüt ve sermayenin hareketliliğinin artırılmasına ve aile yapısının ve ilişkilerinin hızla çökmesine ve dağılmasına dayanmaktadır.

4) Kütle üretiminden elde edilen gelirin azalması ile verimliliğin azalmasının birbirinden farklı durumlar olduğunu fark etmek gerekmektedir. 
5) İş ilişkisi ile ücretlerin parçalanması, bilgi teknolojilerine dayanan sosyalizasyon, bireyselleşme ve yaşam biçiminin çeşitlendirilmesi, rekabetin çalışanlar arasında artırılması, müşteri çeşitliliği, bunların yanı sıra iş disiplininin, ücretlerin standart hale getirilmesinin personel üzerindeki gerginliği yükseltici etkisinin düşürülmesi ve çalışanların işerine son verilmesinin sosyo-psikolojik yapısının ve işleyişinin ve etkilerinin düzenlenmesi üzerine oluşturulmuştur.

Post-fordist birikim rejimi döneminde örgütlenme ve üretim şekli yeniden kurulmuştur. Örgütlenme biçimi ve yönetim felsefesinin temelini toplam kalite yönetimi (TKY) oluşturmuştur. TKY'nin uygulanmasının sonucu olarak, esneklik, taşeronlaşma ve parçacıllaşma yaygınlaşmıştır (Sarı̈ürk, 2009: 28). Neo-liberalizm, Post-fordist dönemde, piyasa mekanizmasını temel alan ve özel girişim üzerine tesis edilmiş düzenlemeleri gerçekleştirmiştir. Liberal ideolojide devletin temel görevi, piyasa şartları ile kurallarının devamlılığını sağlayacak ve teminat altına alacak uygun ortamın oluşturulması ve sürdürülmesidir. Liberalizmde rekabet, kaynak kullanımının verimliliği sağlamak açısından olmazsa olmaz bir ön şart kabul edilmiştir. Fakat, devletin ekonomik mecburiyetlere dayalı olmayan ve bu nedenle ekonominin siyasal nitelikte, kapitalizmin ekonomik rasyonalitesine uymayan kararlara göre yönetilmesi anlamına gelen ekonomik faaliyetlerinin sona ermesi gerektiği ve özellikle liberal ideolojik anlayışa göre, siyasetin ve siyasal kararların ekonomik etkinlik ve verimliliği olumsuz yönde etkilediği için ekonomik alanda yerinin olmayacağ1 belirtilmiştir. Liberalizm, ekonomik kararların, mümkün olduğu ölçüde ekonominin kendi dinamiklerine uygun olarak ve kapitalist ekonomi ilkelerine göre alınmasını ve uygulanmasını uygun görmekte, devlet, kapitalist ekonomik yapının rasyonel zemini olan piyasa şartlarının kendi mantığı içinde ve engellenmeden işleyebilmesi için gerekli zemin ve kurumları oluşturmakla yetinmelidir. Post-fordist dönemde, dünya ekonomik sisteminin neo-liberal yapısının prensip ve değerlerinin Dünya Bankası, Uluslararası Para Fonu (IMF) gibi bazı uluslararası kurum ve kuruluşlarca teminat altına alındığı görülmektedir (Şahin, 2015: 19).

TKY, kapitalizmin, ulusal ekonomi ve sosyal devlete dayalı fordist döneminden yeni oluşan esnekliğe dayalı sermaye birikim dönemine ve yoğun rekabet ortamında oluşan post-fordist birikim rejimi dönemine geçişin sonucu olarak, kütlesel üretim yöntemini uygulamaktansa talep oluşturulmasına, küçük üretim birimlerinde değişik ürünlerin “anında üretim”inin yapılması esasına dayalı yeni bir model olarak geliştirilmiştir. Değişen teknolojinin de bir sonucu olarak otomasyonun gelişimi ve üretimin elektronikleşmesi kapitalizme ve onun ihtiyaçlarının sağlanmasına yönelik rekabet gücünü geliştirici, verimlilik, kalite ve hız 
özelliklerini yeniden oluşturarak devamlılı̆̆ının güvenliğini sağlamış; üretimin örgütlenmesinde bilgi ve yenilik ve belirleyici unsurları oluşturmuştur. Bu özellikleriyle kapitalizmin küresel ihtiyaçlarına cevap veren üretim yapısı ve işleyişi; çatışma yerine ahengi hedeflediği iddia edilen, hiyerarşi yerine katılımı, özerklik ve öz yönetim ve benzeri nitelikleriyle daha katılımcı bir sonuç elde ederek çalışanların insan olma özelliğini etkinlik ve verimlilik için daha etkin kullanmayı sağlayan bir çalışma atmosferi oluşturduğu kabul edilen yeni bir örgüt biçimi olarak TKY anlayışı ve uygulamaları ile bütünleşmiştir (Sarıtürk, 2009: 28). YKYY'nın küreselleşmesinde TKY, belirleyici bir etkiye sahip olmuştur. Devletin post-fordist birikim rejimine uygun olarak yeniden tesisinde ve çalışma anlayışının ve biçiminin yerleştirilmesinde örneklik sağlamış ve yeni dönem uygulamalarının sosyal meşruiyetinin zeminini oluşturacak kavramları ve çevreyi temin etmiştir. Esneklik, yenilik, reformasyon kavramları etrafında oluşturulan yeni örgütsel geliştirme çalışmalarında kamu yönetimini ve özel sektörü, yönetimin temel ilkeleri ve hedefleri bakımından da ortak bir payda da buluşturulmuştur (Farazmand, 2002: 15).

Sabel ve Piore esnek uzmanlaşma anlayışını geliştirmiş, fordist birikim rejiminde oluşan krizin sona ermesi için teknolojik paradigmada dönüşüm sağlanması ve düzenleme biçiminin değiştirilmesi ile mümkün olacağını ifade etmektedir. Fordizmin krizlerine, esnek uzmanlaşma ile çözüm geliştirilmiştir. Bu çözümün doğal sonucu olarak büyük ölçekli örgütlerden esnek üretimin yapıldığı ve dikey entegrasyon yapısının çözüldüğü küçük ölçekli ekonomik birimlere doğru bir değişim, esnek uzmanlaşmanın uygulanmasının sağlanması için gerekli teknik yenilikleri içeren veya üretimi anında stoksuz olarak gerçekleştirebilmeyi sağlayacak şekilde gelişen örgütsel yenilikler barındırmaktadır (http://sol.ccsa.ufrn.br/).

Esneklik kavramı, işçi/işveren ilişkileri ve örgütlenmede girift ilişskileri ve uygulamaları anlatabilmeyi sağlamaktadır. Esneklik anlayışı ve uygulamaları ile birlikte genel olarak örgütlerin weberyen hiyerarşik düzeni değişmiş, Japon yönetim teknikleri ve takım çalışmalarının uygulanması yaygınlaşmış, ücret sistemleri ve çalışma süreleri ile ilgili değişen uygulamalar ortaya çıkmış ve yaygınlaşmış, çok görevlilik ve coğrafi hareketlilik gelişmiş ve bağımsız çalışma gibi çalışma biçimleri gelişmiş ve istihdam alanında yeni türler ortaya çıkmıştır (Vielle,2003;7). Esnek çalışma yöntemlerinin yaygınlaşmasının bir sonucu olarak istihdam atipikleşmeye başlamıştır (Kök, 2006: 106). 
Esnekliği niteliği bakımından nicel ve nitel esneklik olarak konumu bakımından ise dış ve iç esneklik olarak sınıflandırmak mümkündür. $\mathrm{Bu}$ esneklik sınıflandırılmalarını birbirleri ile ilişkili olarak değerlendirildiğinde; sözleşme tiplerini ve istihdam statüsünü dış nicel esneklik olarak sınıflandırılmıştır. Dış nitel esneklik, bağımsız çalışma ve taşeron kullanılarak oluşturulan üretim sistemleri ile birlikte coğrafi esnekliğin yanında taşeron istihdamındaki istihdam şekillerini de kapsamaktadır. İç nicel esneklik, esnek çalışma şekilleri ile süreleri belirtmektedir. İç nitel esneklik, işlevsel örgütsel esnekliği ile iş örgütlenmelerini belirtmektedir. (Sarı̈ürk, 2009: 31).

Post-fordizm uygulamalarının yaygınlaşmaya başladığı dönemde, esneklik, fordist birikim rejiminden post-fordist birikim rejimine geçişin odak noktasındadır. İstihdam şekillerini değiştirmeyi mümkün hale getiren teknolojilerin gelişmesi ve yaygınlaşması, uluslararası rekabetin, nispî olarak yüksek ücretlerin ve sosyal güvenlik alanındaki harcamaların artması sebebiyle firmaların rekabet gücünün düşmesi ve taleplerdeki değişimlere uygun cevabın zamanında verilememesi esneklik yaklaşımının yaygınlaşmasının asıl nedenleridir. Esneklik, toplumsal yapı ile işleyişini, devletin yapısını, ekonomik yapıyı yeniden yapılandırılmasında belirleyici bir etki oluşturmuş ve post-fordist dönemin tesisinde ana kavram konumunda yer almıştır (Sarıtürk, 2009: 31).

Post-fordist dönemde istihdam statüsü ve yapısı yeniden oluşmuş, geçici istihdam uygulamaları ve atipik istihdam yöntemleri yaygınlaşmıştır. Özelleştirme uygulamaları sonucunda dış esneklik uygulamaları kamu yönetiminde de gerçekleştirilmiştir. Bu durum, kamu çalışanlarının istihdam biçimini değiştirmiş aynı zamanda da istihdamın yeniden sınıflandırılması sonucu, değişik kamu çalışan gruplarının idaredeki istihdamının toplam istihdam içerisindeki ağırlığını yeniden oluşturmuştur. Kamu istihdamında, dış esneklik uygulamalarının kapsamında nitel özellikler gelişmiştir. Üretim sistemleri, nitel özelliğe sahip esneklik anlayışının sonucunda esnekleşmiştir. Yerel yönetimlerden başlayarak kamu örgütleri, kamu bürokrasisinde ve devletin izin verdiği veya çekildiği konularda kamu özel tüzel kişilerinde ya da özel kişilerde yaygın olarak taşeron kullanılmaya başlanmıştır. Üretken coğrafi esneklik, bir başka dış nitel esneklik uygulaması örneğidir. Dış nitel esneklik uygulamaları arasında mahalli idarelerin güçlendirilmesi, bağımsız idari otorite (BİO)ler, bölgesel kalkınma ajansları bulunmaktadır. Dış nitel esneklik özelliği taşıyan örgütlenmeler yaygınlaştıkça kamu yönetiminin yapısı da parçacıllaşmaktadır. İstihdam biçiminin değişmesi ve bu tip örgütlerin yaygınlaşması, kamu yönetiminin istihdam ve örgütlenme karakterini oluşturmaktadır. İç esneklik uygulamaları da kamu yönetiminin yapısını değiştirmektedir. İç 
nicel esneklik uygulamaları kapsamında, istihdamın niteliği ve çalışma saatleri değişmektedir. Memur sayısı azaltılmakta, sözleşmeli çalışan sayısı çoğaltılarak sözleşmeli çalışanların yaygınlaştırılması iç nicel esneklik şeklinde oluşmaktadır (Sarıtürk, 2009: 52).

Nitel özellikte iç esneklik ise işlevsel örgütsel esneklik ve iş örgütlenmeleri şeklinde oluşmaktadır. Çalışanların birden çok görevi bulunmakta ve sayıca azaltılmaktadır. Dikey ve yatay esneklik, örgüt içerisinde yaygınlaşmaktadır (Sarıtürk, 2009: 53).

Esneklik, bürokrasinin öncesine göre daha yüksek başarım ihtimali varsayılarak kararlar ve faaliyetlerde kanun yoluyla oluşturulanlar haricindeki usul ve esaslar bakımından nispî otonom davranışlara müsaade etmesi anlamına gelmektedir. Esneklik, hesap verme sorumluluğunu gerektirmektedir. Hesap verme sorumluluğu ise politik ve idari birimlerin, yetkilerine dayanarak kullandıkları kaynak ve güçlerin kullanım şekli, diğer bir anlatım ile kullanım amacının hangi oranda amacına ulaştığg ya da etkinliği hakkında vatandaş, yönetim, denetleyici birimler ve kanun yapıcı nezdinde sorumlu olmalarıdır. İdareye belli faaliyet ve kararlarda esneklik sağlanmıştır (Aydemir, 2005: 26). Esnek hale gelen kamu yönetimi, temel prensibi regülasyon olan, geçici personel ve sanal örgütler aracılığı idare edilen, politika yapımını yeniden uygulamalar ile gerçekleştiren, devletin masraflarını azaltmaya ve farklı çıkarları kendi arasında uzlaştırma ve ahenk oluşturmayı hedefleyen bir yapıdadır (Frederickson, 2004: 11). Regülasyon, dar tanımıyla, daha önceden kamusal özelliği bulunan hizmetler olarak kabul edilen ve kamu girişimlerince tekel olarak yürütülen elektrik dağıtımı, demiryolları, doğalgaz dağıtımı ve benzeri kıt olan mal ve hizmetlerle ilgili rekabete açılan ekonomik faaliyetleri kapsamaktadır. Geniş tanımıyla ise, regülasyon, belli bir sektördeki ekonomik faaliyetin haricinde bütün piyasayı kapsayıcı bir faaliyettir (Erdoğan, 2016;569).

YKYY ve TKY, politik ve bürokratik kültürü yeniden oluşturmuş ve çıktının kurallardan daha önemli olduğu bir anlayış ve uygulama geliştirmiştir. Bürokrasi, karar vermeye odaklı ve âdem-i merkezileşmiştir. Bürokrasinin örgütsel yapısı, sosyal bağları ve dış çevredeki ekonomik, kültürel ve politik değişimin etkisi ile yeniden yapılandırılmaktadır. Parçacıllaşma ve yönetişimin sonucunda ağ yapısı oluşmakta ve örgütlerin kendi aralarındaki hiyerarşik olmayan ilişkiler önemini artırmış, örgütlerin sınırları ise geçirgen hale gelmiştir. Esneklik anlayışı ve uygulamaları kamu örgütlerini zorunlu olarak değiştirmiş, müşteri tercihlerine ve değişen piyasa şartlarına uygun adem-i merkezileştirilmiş örgütsel süreçler ve yapılar kamu yönetiminde de ortaya çıkmaya başlamıştır (Parker ve Bradley, 2004: 11). Weberyen 
bürokrasinin uygulamalarının yerine hiyerarşik katmanları daha az ve zayıflatılmış sonuç yönelimli yeni kamu örgütleri de baskın örgüt modeli olmuştur (Özer, 2005: 11).

Post-fordist dönemin başlamasıyla weberyen ve fordist bürokrasi yapısı ve anlayışı değişmeye başlamış esnek, post-fordist; parçacıl, kamu hizmeti kavramı ve kamu yararı anlayışı yerine YKYY'nin esneklik ve TKY ile belirtilen amaç ve ilkeleri esas alınmıştır. Esnek birikim rejiminin gereği olarak her şey yeniden düzenlenirken kamu yönetimi de yeniden yapılandırılmıştır ve BİO’lar gibi yeni kurumlar tesis edilmiştir (Sarı̈ürk, 2009: 70). BİO’ların oluşturulma ve yaygınlaşması küresel seviyede regülasyonun yaygınlaştığ dönemde gerçekleşmiştir. Ayrıca, BİO’ların oluşturulması ile özelleştirme ve “düzenlenmiş piyasa ekonomisi"nin sosyal devlet politikalarının yerini alması arasında bir ilişki bulunmaktadır (Egeli, Ay ve Keyifli, 2014: 10-11). Farklı idari geleneklere sahip ülkelerin, düzenleyici kurumların kurumsal modelini uyarladıklarını ve özellikle toplumun katılımı ve örgütlerin bürokratik özerkliği ile ilgili olarak geleneklerine göre daha fazla yeni kurum geliştirdiklerini göstermektedir (Bianculli vd., 2013: 2). Ekonomi alanında farklı sektörlerde ortaya çıkan evrimleşme, bu sektörlerin kendi içinde farklılaşmasına neden olmuştur. $\mathrm{Bu}$ farklılaşma, ilgili sektörlerin yönetimi için kurulan BİO’lar eliyle yönetilmesi uygulamasına neden olmuştur. Hükümetten bağımsız olarak genel kararlar alıp uygulayan, sosyal devlet ile düzenleyici devlet arasındaki fark oluşmuştur. BİO’lar, sermayeye, düzenlemelerin, genel düzenleyici ya da piyasa aktörü olarak devletin çıkarlarından etkilenmediğini garanti altına almanın mümkün hale geldiğini göstermektedir (Nunes, Nunes ve Rego, 2015: 5).

BİO’lar, devletin yeniden bürokratikleştirilmesi/yapılandırılması sürecinin ayrılmaz parçasıdır ve hizmet sunumu yerine düzenleme ve yönetişim sisteminde merkezi konumdadır (Jordana, Levi-Faur, David, 2009: 5, Flinders, 2004: 522). Esnek birikim rejimi uygulamalarının gerçekleştirildiği dönemde, kamu yönetiminin esneklik kaynaklı teknikleri ile daha fonksiyonel hale gelen yeni BİO'lar oluşturulmuştur. Post-fordist dönem regülasyonu, merkezi idarenin denetiminin zayıflamasına, yapısal değişime, idari özerkliğe ve özelleştirmeye neden olmuştur. Artan bir takdir yetkisi ve esneklik ile güçlendirilerek, performans ve regülasyon temelli bir idare tesis edilmiştir (Christensen, Lægreid, 2005: 24). Bağımsız uzmanlar ve düzenleyici kurumlar, modern düzenleme sistemlerinin ayırt edici kurumlarıdır. Bağımsızlıkları ve yönetişim sistemindeki konumları farklı kamu yönetimi ve hukuk sistemlerinde farklıdır. Fakat, bütün sistemlerde merkezi yönetimden uzağa yerleştirilmişlerdir (Eyre vd., 2016: 1). BİO’lar, özel sektör anlayışına uygun olarak tesis edilmiş ve özel sektör gibi inisiyatifi bulunan kamu gücünün esnek kurumları (Wettenhall, 
2005: 627) olurken, bakanlık tipi merkezi örgütlenmeyi de ikame etmeye başlamıştır (Bayramoğlu, 2002: 109; Bafra, 2011: 453).

Düzenleyici kurumlar, birbiriyle ilişkili iki kurumsal ve politik dinamiğgin kesişme noktasında durmaktadır: Ajanslaşma ve düzenleyici genişleme. Ajanslaşma, bir kurumun; yapısal olarak ayrıştırılmış bir organ olarak kurulmasını ifade etmektedir, resmi olarak bakanlıktan ayrı bir kurum olarak, ulusal düzeyde kamu görevlerini sürekli olarak yerine getiren, kamu görevlileri tarafindan yönetilen, esas olarak devlet bütçesi tarafindan finanse edilen ve konu kamunun yasal prosedürlerine göre yönetilen örgütlerdir. Öte yandan, düzenleyici genişleme, son yıllarda düzenleyici politikaların ve araçların dünya çapında yönetişim modları olarak kullanılmasında bir artışı temsil etmektedir. Genellikle piyasanın serbestleştirilmesi ile ilgili çok sayıda sektörde çok sayıda düzenleyici reform, aynı zamanda ekonomik düzenleme mantığının ötesinde, yani sosyal ve risk önleme alanlarında, sözde düzenleyici devletin genişlemesine katkıda bulunmuştur. Düzenleyici genişleme her zaman bir düzenleyici kurumun kurulmasının sonucu değildir ve birçok yerleşik kurum da düzenleyici nitelikte değildir. Bununla birlikte, düzenleyici kurumun örgütsel modeli, mevcut idari dünyada bir standart haline gelmiştir (Bianculli vd., 2013: 4). BİO’ların temel görevi düzenleme/regülasyondur. En geniş anlamda, düzenleme, amaçlanmamış eylemler ve devlet dışı süreçler de dahil olmak üzere tüm sosyal kontrol kurallarını ve mekanizmalarını ifade eder. Düzenlemenin ikinci anlamı ise, devletin ekonomiyi yönlendirmek ve "kamu yararını" teşvik eden bir dizi hedefi desteklemek amacıyla özel alana yapılan devlet müdahalesidir. $\mathrm{Bu}$ anlamda, devlet müdahalesi, kural koyma ve uygulamaya ek olarak vergilendirme, sübvansiyonlar, yeniden dağıtım ve kamu mülkiyeti gibi çeşitli önlemleri kapsar. Düzenleme, yetkili kural kümelerinin yayınlanması yoluyla faaliyet gösteren ve bu kurallara uyumu izlemek, incelemek ve teşvik etmek için mekanizmalar oluşturan belirli bir yönetişim biçimi olarak tanımlanabilir. Bu düzenleme şekli, tipik olarak BİO’ların çalışmaları aracılığı ile gerçekleştirilmektedir. Düzenlemenin ajanslaşmayla birlikte gittiği belirtilmekte ve iki fenomen karş1lıklı olarak birbirini güçlendirmektedir. Son yirmi yılda liberalizasyon, özelleştirme ve deregülasyona yol açan siyasi kararlar, piyasaların yeniden düzenlenmesi ihtiyacını ima ederken, yeni kuralların geliştirilmesi bağımsız düzenleyicilerin oluşturulmasını gerektirmiştir. Buna karşılık, düzenleyici kurumların kurulması, yeni düzenleme teknolojilerinin geliştirilmesini teşvik etmiş ve devlet tarafından da düzenleyici yönetişimi teşvik etmiştir. Bu bağlamda, önemli düzenleyici işlevler BİO'lara devredilmiştir. Bu işlevler: 
hedef oluşturma, kural koyma ve standart belirleme; izleme ve kontrol, bilgi toplama, inceleme, gözetim, teftiş, denetim ve değerlendirme; uygulama, davranış değişikliği, yargılama ve ödül ve yaptırımların uygulanmasıdır. Ajanslaştırma ayrıca, örneğin performans değerlendirmesi, uygunluk değerlendirmesi, hükümet denetimi, sözleşmeye dayalı hale getirme ve gözetimi birleştiren kamu idaresinin dikey ve yatay kurumlar arası görevlerinin karmaşıklaştırılmasını da içermektedir (Maggetti, 2012: 7).

BİO’larda, sözleşme ve satın alma uygulamaları, personel ve bütçe konularında artan bir esneklik uygulaması bulunmaktadır. Personel yapısı değiştiği zaman, takdir yetkisinden kaynaklanan uygulama ve kararlar idarecinin konumuna göre oluşturulmaktadır. Bu durumun sonucu olarak, farklı maaş grupları oluşmakta, bu durum da çalışan ile ilgili kurum arasındaki anlaşmasının içeriğini, beklentilerini, idarecinin eğilimi ve sorumluluğu ile performansı ifade etmektedir (Joint Legislative audit Committee, 2004: 4).

Dikey bütünleşik örgütlerin parçalanarak, parçaların esnek bir bağ ile ana örgüte bağlandığı ve bağımsız olarak piyasada bulunmasındaki uygulamaya uygun olarak devletin de BİO'lar aracılığı ile parçacıllaşması sağlanmıştır. Dikey örgütlenme biçimi olan bakanlıklar parçalanarak, BİO’lar oluşturulmakta, kamu bürokrasisi esnekleştirilmekte ve yatay olarak şekillendirilmektedir. BİO’lar, dikey bütünleşik örgütlerin parçalanması ile ortaya çıkan ve ana şirket etrafında taşeron şirketlerin faaliyet yürüttüğü sektörlerde ana şirketlerin ifa ettiği göreve benzer bir görevi, devlet yapısı içinde bulunmanın gerektirdiği özelliklerle girift bir yapıda ve görev alanında yerine getirmektedir. BİO'ların, her ülkede kendine has uygulamaları bulunsa da bakanlıkların gücünü paylaşmasının yanı sıra, aynı zamanda da ana şirketlerin, taşeron şirketler üzerinde sahip olduğu etkiye benzer bir şekilde, organizasyon şeklinin ortaya çıkardığı bir durum olarak içinde bulunduğu sektör üzerinde ana şirketin regüle edici "ana şirket" fonksiyonunu yerine getirmektedir. Bu fonksiyonunda, yönetişim tekniğinin uygulamalarının gereği olarak sermayeye ile bütünleşmekte, bundan dolayı, kamu örgütlerindeki parçacıllaşma, idare usulleri ve araçları kullanılarak gücü artırılan üst kurulların, bir bakımdan merkezi yönetime karşı esneklik sağlanarak güçlendirilmiş olmasına rağmen devletle arasında oluşturulan esnek bağ ile ortaya çıkan boşluk, sermaye tarafından yönetişim uygulamaları ile doldurulmaktadır. Bu durumun sonucu olarak sektörün "ana firmaları" ve BİO'ların, BİO'ların karar mekanizmalarının örgütsel yapısından uzak bir konumda kurularak, gerçekleştirilmek istenen esnekliğin, esnekliği meşrulaştırmak için oluşturulan söylemin ileri sürdüklerinin tersine, piyasa ekonomisine ve mali güce bağımlılığ1 ile zayıflatıldığı bunun sonucunda da devletin örgütsel yapısında, örgütlenme ile istihdamın, 
YKYY'nın içerdiği esnekliğin oluşturulsa bile, ilgili örgütlerde, piyasa ve sermaye bağımlısı bir sonuç oluşturmaktadır. Sermayenin devlet içindeki varlık ve gücünü BİO’lar, ekonomizm kavramı ve profesyonalizm anlayışıyla siyasal ve toplumsal alanda kabul edilir hale getirildiği, örgütlenme biçimi ve iş yapma kültürü açısından kamu yönetiminde esnek uzmanlaşmanın somut örnekleri arasındadır (Sarı̈ürk, 2009: 72).

Devletin araçlarını ve kurumlarını düzenli bir şekilde geliştirmek, kullanabilmek, bu araçlar ve kurumların düzenleyici özelliklerini geliştirebilmek için düzenleme politikaları oluşturulmaktadır. Düzenleme politikaları, düzenleyici post-fordist politika aşamasında, BİO’ların sonuç odaklı, esnekliğe dayanan varlığına uygun olarak, rekabet politikası bütünleşik hale getirilmiş ve serbest piyasanın önceliği BİO'lar tarafından düzenli olarak oluşturmuştur. (Malyshev, 2006: 276). Bu durum da devletin yeni rolü ve konumu ve ekonomik rekabet değerlendirildiğinde BİO'ların iç niceliksel ve niteliksel esnek yapı ve özellikleri daha kolay anlaşılacaktır. BİO’lar, weberyen yapıdaki fordist dönem bürokrasi ve kamu yönetimi işleyiş ve yapısını çözen ve post-fordist birikim rejimi döneminde YKYY'na en uygun çalışma ve istihdam şartlarına sahip olan kurumlardır. BİO’larda çekirdek kadroların merkezde bulunduğu bir yapıya bağlı olarak işlevsel ve sayısal işlendirme şekillerini, coğrafi ve finansal esneklik yöntemini uygulamaktadırlar (Sarıtürk, 2009: 72).

Kamu yönetiminin ayrıştırılması ve parçacıllaştırılmasını bu tip örgütlerin yanı sıra çok sayıda unsur etkilemiştir. Çevre ile merkez arasında çoğalan münasebetlerin derinleşmesi ile beraber bölgelerdeki ve mahalli olan karar alıcıların belirleyici olduğu düşünülen güçlenmesi ve çoğalması kamu yönetiminin örgütlenmesinin tekrar oluşturulması, küresel seviyede düzenleyici yapının yaygınlaştırılması ve bu durumun sonucunda oluşan karmaşık ve çok katmanlı model, YKYY anlayışına dayanan işletme yönetim tekniklerinin kamu bürokrasisinde de uygulanması devletin yapısındaki parçacıllaşmayı ve ayrışmayı yaygınlaştırmıştır (Cassini, 2007: 22). Parçacıllaşma uygulamaları metot olarak ise işin ve örgütün fonksiyonel uzmanlaşma ve otonom alt sistemlere bölünmesi yöntemi ile uygulanmıştır. Bahsedilen iki uygulama birbirini tamamlamaktadır. Bağlılık karşılıklı olsa da ilgili uygulamalardan her birisi diğerine karşı çoğunlukla yasal olarak kayıtsızdır (Christensen; Lægreid, 2005: 1).

Post-fordist dönem ile birlikte, dikey bütünleşik olarak örgütlenmiş olan kamu yönetimi, parçacıl ve yatay olarak hızlı bir şekilde tekrar şekillendirilmiştir. Bu durumun asıl nedeni, 
regülasyon faaliyetlerinin örgütlenmesidir. Tepe yönetimi ve bürokrasinin esas yetki ve sorumlulukları büyük ölçüde BİO’lara aktarılmıştır. Üst yönetimin merkezi kontrolüne ve idaresine dayanan regülasyonun, BİO’ların kurulması ve geliştirilmesi ile tepe yönetimi kaynaklı olma özelliği zayıflatılmıştır (Christensen; Lægreid, 2005: 2). Tipik bir parçacıllaşma olan düzenleyici yönetişim çalışmaları, BİO’lara kaynak ve yetki devri yoluyla gerçekleştirilmiştir. Bu yeni kamu yönetimi yapısı BİO’ların kamu yönetiminin diğer aktörleri içinde ve kendi aralarında, çoğu zaman birbirine bağlı olmayan farklı biçimler ve politika setleri kurgulanmaktadır. Değişik modellerde örgütlerde kendisi dışındaki kurumlara yönelik olarak gerilim kaynağı olacak çeşitli rasyonel sonuçlar oluşmakta ve bu sonuçlar da kamu bürokrasisinin ve siyasal yapının fikri özelliklerinin de parçacıllaşması sonucunu ortaya çıkarmaktadır (Scott, 2000;3). Evrensel bir kamu yönetimi reformu örneği iddiasının oluşması ile kurulan yeni küresel regülasyoncu katı yaklaşım, BİO'ları demokrasi ve siyasal kontrol benzeri ilkeler nedeniyle olumsuz etkiler oluşturulmadan performans ile birlikte verimi artırarak devam ettirmeye çaba göstermiştir (Christensen; Lægreid, 2005: 2). Örgütsel parçacıllaşma gerçekleştirilerek idari açıdan esneklik oluşturulmasının yanında son derece sınırlı ölçüde parlamenter denetim ve hesap verilebilirlik sağlanmıştır (Nölke, 2004: 11). BİO’lar, Kamu gücünün belirli alanlarında oluşturulmuş otorite ve uzmanlık sahibi resmî kurumlar olmasının yanında, halkın iradesini temsil eden siyasetçiler tarafından doğrudan yönetilememesi açısından da fordist devletin diğer örgütsel yapılarından ayrılmaktadır. Halkın iradesini temsil etmemesine rağmen kendi alanlarında politikaların belirlenmesinde önemli rol oynamaktadırlar (Iliman, Tekeli, 2016: 25). BİO’larda, siyasa oluşturma faaliyetlerine herhangi bir siyasi sorumluluğu bulunmayan, neo-liberal anlayışa uygun olarak, teknokratların katılması teknokrasi olarak değerlendirilebilir. Siyasi bir sorumlulukları bulunmamasına rağmen siyasa geliştirme ve piyasaların regüle edilmesi çalışmalarında kullandıkları yetkinin meşruiyeti ve idare yapısında konumlandırılacakları yer problemi, idari ve siyasi tartışma ve belirsizlik konusu olmuştur (Arslan, 2017: 6).

BİO’ların hem dış etkilerin artmasında hem de devletin iç örgütlenmesinin parçacıllaşmasında önemli fonksiyonları bulunmaktadır. Devletin iç yapısının parçacıllaşması, yapısal bir devrime neden olmuştur. BİO’ların, uzmanlaşma esaslı ve tek amaçlı örgütler olması, merkezi bürokrasinin siyasa kapasitesini azaltmıştır. Parçacıllaşma ve kapasitede ortaya çıkan düşüş eşgüdümleme sorunlarının oluşmasına sebep olmaya ilaveten yüksek seviye politik idarecilerin politik kapasiteleri ve etkileri azalmaktadır. Bu durumun nedeni, bol miktarda idarî ve politik sorun güç kaybetmiş ve karar seviyeleri azalmış bir örgütsel yapı içerisinde 
hükümetlere yönlendirilmiştir. Koordinasyon probleminin artması ve bunların çözülebilmesi için weberyen bürokrasi ve bakanlıkların dikey, bakanlıklar ve BİO’ların yatay yapıdaki siyasal eşgüdümlemesi, YKYY'nın köktenci çözümü kabul edilerek gerçekleştirilmektedir (Christensen ve Lægreid, 2005: 20).

BİO’ların, uluslararası etkilerle devletin parçacıllaşmasına etkileri oluşmuştur. Ekonomik ilişkilerin artması ve ekonominin küresel akışının hızlanmasının sonucunda ulusal hakimiyetin yapısında parçalanma artmış ve devletin uyumunda, örgütsel yapısı üzerinde parçacıllaşmaya yönelik bir etki oluşmuştur. Özel sektör bileşenleri daha da güçlenerek sayıca artmış ve yaygınlaşmış, uluslararası, ulusal, ülke içinde bölgesel ve yerel seviyelerde bürokraside ve siyasal alanda politika oluşturulması ve yürütülmesinde devletin merkezi nitelikteki karar ve uygulamaları, koordinasyon ile yönetim niteliğinin ana sistem ve çalışmasını yönetmiştir (James, 2007: 27). Devlet bünyesinde farklı üst kurullar yüksek bir bağımsızlık ve özerklikle oluşturulmuştur. $\mathrm{Bu}$ parçacıllaşma, kamu yönetiminin örgütsel yapısındaki gerçekleştirilmiş ve regülasyoncu yönetişimin uluslararası biçimi eliyle geliştirilmiştir. Ekonomi alanında ortaya çıkan küresel yönetişim, üst kurulları ve küreselleşmenin geliştirerek yaygınlaştırdığı bu döneme ait iktisadi ve siyasi örgütleri uluslararası hale getirmiştir. Ulusaşırı politik ağın temel niteliği, devletlerin örgütsel yapılarının düzenlemesini sağlamasıdır. Merkezi devlet yapısı, devletin kendisi, özel sektör ve bileşenleri ile diğer devletlerle yükssek seviyeli kaynak değişimine ihtiyaç hissetmeyecektir. Fakat, yapısı parçacıllaşan devlet ise kaynaklar, değişik seviyelerde ve yatay konumda olan üst kurullar, bakanlıklar, mahalli idareler veya federal devletlerde, federal devlet hiyerarşisi bünyesindeki federal alt bürokratik birimler benzeri birimler arasında pay edilecek ve uygulamanın neticesinde de politika ağlarının sayısı ve işleyiş̧i artacaktır. Bu durum yalnızca ülkede ulusal aktörler bakımından kaynak dağıtımında belirleyici olmayacak, ulusaşırı teşkilatların menfaatlerini sağlamasını kolaylaştıracaktır (Nölke, 2004: 27). Üst kurulların, ulusaşırı teşkilatlarla ulusal devlet ve bürokrasi arasındaki bağlantıda önemli bir yerinin olması özerkliklerini ve bağımsızlıklarını artırarak parçacıllaşmayı güçlendirmiştir. Ulusaşırı ekonomik ve siyasal ağ vasıtası ile ilgili aktörler, ekonomik kaynaklara yönelerek, parçacıllaşmış siyasal sistemden dolayı ve BİO’lar aracılığı ile onların oluşturduğu bol ve kolay ulaşılabilir bilginin karar almayı kolaylaştırmasının sonucunda işleyişe dahil olabilmektedirler (Nölke, 2004: 12). 
BİO’ların yaygınlaşması ile birlikte, kamu yönetiminin temel yaklaşımlarının yanı sıra personel uygulamaları yeniden şekillendirilmiş (Frederickson, 2004: 22), bakanlık olarak teşkilatlanan merkezi idarelerin karma görev ve işlevleri bölünmüştür (Christensen ve Lægreid, 2007: 503). Fordist bürokrasi, diğer birimlerle görevleri paylaşarak ifa ederken, düzenlenenler ile düzenleyici bürokrasi arasında örgütsel farklılaşma ortaya çıkmıştır. Üst Kurullar için bir takım kendisine göre örgütsel düzenleme ile emir davranışlarının olması ve bir takım otoriter asıl özellikleri BİO’ları, BİO’lar dışındaki kamu kurum ve kuruluşlarından ayırmaktadır (Hood vd., 1988: 61). YKY yaklaşımı, düzenleyici devlet uygulamaları ile müşteriden tedarik edene yönelik olan, düzenleyici faaliyetlerle eylemsel nitelikteki ve politika yapma fonksiyonu ile de politika uygulama fonksiyonunu birbirinden ayırmıştır. Fordist birikim rejimine zıtlık oluşturan özellik, regülasyoncu devlette, tek amaçlı ve yalın örgütlerle üst kurullar vasıtasıyla gözetime önemli derecede değer verilmiştir (Christensen, Lie ve Lægreid, 2008: 15). BİO çatısı altında birleştirilmiş otonomiye, uzmanlığa sahip ve belirli konularda görevler ve uzmanlık bilgisi bulunmaktadır. Bu hal ve özelllikler, üst kurul ve bakanlıkların birbirleri ile hiyerarşik ilişkiler kurmasını engellemesine ilaveten ve BİO’ların kendi aralarında da yatay ilişkiler gelişmesini sağlamaktadır. $\mathrm{Bu}$ durum, koordinasyon ihtiyacının artmasına ve örgütsel karmaşıklığa yol açmaktadır. Yapısal değişim, düzenleyici reformların ve BİO’ların aynı zamanda ortaya çıkmasına neden olmuştur (Christensen, Lie ve Lægreid, 2008: 17).

Refah devletinin kaynak ve yöntemleri devlete aitti ve kamu mülkiyetindeydi. Fordist birikim rejimi döneminde kamu yararı amacı ve kamu hizmetleri devlet tarafindan uygulanmaktaydı, kamu politikalarının gereği olarak devletin fonksiyonuydu. Düzenleyici devlet ve post-fordist birikim rejiminde ise bunun aksi bir durum ortaya çıkmakta, politik alanlardaki bazı düzenleyici etkinlikler bile yönetişimin bir kısım karmaşık yapısına ve işleyişine uygun olarak, yürütme gücü kapsamındaki işlevleri parçalanarak BİO’lara devredilmiştir. Yürütme ve bürokrasinin yanı sıra üst kurullar, standartların tespiti, gözetim ve denetime ilaveten müeyyidelerin uygulanmasını gerçekleştirmektedir (Scott, 2003: 4).

BİO’ları kamu yönetimi yapısı içerisinde diğer kamu örgütlerinden ayıran bazı özellikleri bulunmaktadır (Ekelund, 2007: 7):

a) BİO’lar, devletin merkezi idaresinin hiyerarşik düzeninden ayrılmaktadır. Çoğunlukla bakanlık örgütlenmelerinin örgütsel yapısının dışında kurulmaktadırlar.

b) Vazifelerini ulusal düzeyde yerine getirmektedir. 
c) Kurulduğu ülkede aynı alanda sadece bir BİO kurulmaktadır.

d) Kamu yönetimi bürokrasisinde görev alan memurlar BİO’larda görevlendirilmektedir.

e) İlkesel olarak, merkezi idare yapısı içerisinde genel bütçe ile mali kaynağı sağlanmaktadır. Fakat, ayrıca bütçelerini kendileri hazırlamaktadırlar.

f) BİO'lar kamu hukukuna zayıf bir bağ ile bağlıdırlar. BİO’lara aktarılan bağlı yetki, onlara çok geniş bir hareket ve düzenleme alanı oluşturmaktadır.

g) Bağımsızlık özelliği BİO’lara, kendisi için bir örgütsel birim oluşturma ve kimliğini tasarlama imkânı vermektedir.

h) Çoğunlukla küçük, tek ya da sınırlı bir alanda görevlendirilerek kurulmaktadırlar.

i) BİO’ların gerçekleştirmek için oluşturuldukları görevler, dağıtım, uygulama, yorum, yargı ve danışma konuları hakkındadır.

j) Belirgin, net özellikte ana bir kurucu hukuksal belge ile tesis edilerek yapılandırılmaktadırlar.

k) Çoğunlukla, bünyesinde oluşturulan bir kurul eliyle değil de tek bir yönetici tarafından yönetilerek temsil edilmektedirler.

1) Kendine özgü işe alma usulleri oluşturabilmektedirler.

m) Daha önce kullanılmamış olan yeni biçimsel raporlama teknikleri geliştirebilmektedirler.

Doğrudan doğruya klasik, weberyen bürokratik nitelikte olan, merkezi yönetim teşkilatına dahil olmamakla birlikte, devletin merkezi örgütsel yapısının dolaylı olarak da olsa parçası olan kurumlar olan BİO’lar, tüzel kişiliğe sahip kamu kurumlarıdır, idari-mali özerklikleri bulunmaktadır, çeşitli yetkilerle donatılmış ve yetkilendirildikleri sektör ve alanlarda piyasadan bağımsız, merkezi idareden özerk ve aynı zamanda genel iktisadi politikalarla uyum halinde olması ve hareket etmesi beklenen kurumlardır (Sarısu, 2011: 229).

BİO’ların fordist dönem bürokrasisinden farklı olan en önemli iki özelliği, düzenleme işlevlerinin olması ve idari açıdan bağımsız olmalarıdır. Farklı bir şekilde ifade etmek gerekirse, bir örgütsel yapının BİO sayılabilmesi için düzenleme işlevinin olmasının yanı sıra idari yönden bağımsız olma özelliklerini birlikte taşıması gerekmektedir (Ulusoy, 2003: 15). 


\subsection{EPDK}

EPDK, Resmî Gazetenin 24335 (Mükerrer) sayılı ve 03/03/2001 tarihli yayımında 4628 sayılı eski "Elektrik Piyasası Kanunu” yayımlanarak kurulmuş ve 24390 sayılı ve Resmî Gazetenin 02/05/2001 tarihinde yayımlanan Resmî Gazetede 4646 sayılı "Doğal Gaz Piyasası Kanunu (Elektrik Piyasası Kanunu'nda Değişiklik Yapılması ve Doğal Gaz Piyasası Hakkında Kanun)" ile "Enerji Piyasası Düzenleme Kurumu" adını almıştır. Kurum mali ve idari özerkliğe sahip ve kamu tüzel kişiliğini haizdir. Kurumun Merkezi Ankara'dadır, taşra teşkilatı bulunmamaktadır. Enerji ve Tabii Kaynaklar Bakanlığı ile ilişkilidir. Dağıtım yapılan bölgelerde irtibat büroları kurarak müşteri bağlantılarını ve ilişkilerini sağlayabilmektedir. Kurum; 4628 sayılı EPDK'nın Teşkilat ve Görevleri Hakkında Kanun, 4646 sayılı Doğal Gaz Piyasası Kanunu, 5015 sayılı Petrol Piyasası Kanunu, 5307 sayılı Sıvılaştırılmış Petrol Gazları (LPG) Piyasası Kanunu, 6446 sayılı Elektrik Piyasası Kanunu ile oluşturulan görevleri yerine getirmektedir. Bu kanunlar, petrol, LPG, elektrik ve doğalgazın; kaliteli, sürekli, çevreyle uyumlu ve düşük maliyetli olarak kullanıma arz edilmesinin sağlanması için rekabet ortamında ve şartlarında özel hukuk kurallarına uygun olarak etkinlik gerçekleştirebilecek şeffaf, istikrarlı ve finansal açıdan güçlü bir enerji pazarının ve piyasasının kurulmasını ve kurulan enerji piyasasında bağımsız denetim ile düzenlemenin teminini hedeflemektedir (http://www.epdk.gov.tr/Detay/Icerik/1-1051/kurumsaltarihce 10.02.2021).

EPDK, Başkanlık, Piyasası Düzenleme Kurulu ve Hizmet Birimlerinden oluşmaktadır. EPDK yetkilerini kurul aracı̆̆ı ile kullanmaktadır. Kurul, temsil ve karar organıdır, yedi üyeden oluşmaktadır ve bu üyelerden biri başkan biri ikinci başkandır. Atama ile birlikte kurulun başkanlık makamına atanacak başkanı ve başkandan sonraki konumda olacak olan ikinci başkanı Cumhurbaşkanı görevlendirmektedir. Kurul başkanı aynı zamanda kurumun da başkanıdır. Başkan, kurulu ve kurumu yönetir, kurul kararlarının gereğini yerine getirir ve kurulu temsil eder. Başkanlığın kurum personeline verdiği yetkiler dışında kurumun bütün kararlarını kurul alır. Kurumun bir organı olan kurul, münasip gördüğü konularla ilgili olarak başkanlığ yetkilendirebilir ya da görevlendirebilir. Kurul, ikinci başkan ve başkanın olmadığ durumlarda başkana ait yetki ve görevleri yerine getirir. Başkana, kurul kararı alınarak görevlerinde yardım etmesi için üzere iki yardımcı atanabilir. Kurumun bünyesinde bulunan hizmet birimleri ve hizmet birimlerinin sorumlulukları ve görevleri ve diğer konular 4628 sayılı EPDK Teşkilat ve Görevleri Hakkında Kanun ve EPDK Teşkilat Yönetmeliğinde 

10.02.2021).

\section{ENERJI PIYYASASI DÜZENLEME KURUMU VE ESNEKLİK}

Enerji, varlığın temel kaynağıdır. Her şey enerjiye sahiptir. Evrendeki gerçekleşen her olay enerji kullanılarak gerçekleşmektedir. Gerçekleşen her olay esnasında devamlı olarak enerji hareketi ve dönüşümü oluşmaktadır. İnsanlık da sürekli olarak enerji kullanarak varlığını sürdürmüştür (Yalçın, 2006: 41). Enerji tanımı "iş yapma kabiliyeti veya kapasitesi” olarak yapılmaktadır. Farklı formlarda oluşmakta ve kullanılmaktadır: Elektrik enerjisi, mekanik enerji, kimyasal enerji, 1ş1k (radyant enerjisi), 1sı enerjisi ve nükleer enerji bu formlara örnek olarak verilebilir. Enerji kaynakları, çoğunlukla iki başlık altında sınıflandırılmaktadır; yenilenemez veya tükenebilir enerji ve yenilenebilir enerji. Yenilenebilir enerji, tekrar tekrar üretilebilen enerjidir ve k1sa zamanda yeniden üretilebilir. Kullanılan enerjinin önemli bir kısmı tükenebilir olan petrol, kömür, nükleer enerji vb. kaynaklarından elde edilmektedir. Tükenebilir enerji ifadesi, yaygın olarak kullanılan fakat kısa sürede yeniden oluşturulamayan enerji grubunu ifade etmektedir. Genellikle fosil yakıtlardır (Satman, 2006: 47).

Enerji, üretimin temel girdisidir. Üretim faktörlerinin üretimi gerçekleştirebilmek için kullanılabilmeleri enerji ile mümkün olmaktadır. Ülkelerin kalkınmalarına bağlı olarak, enerji kaynaklarına olan ihtiyaçları da giderek artmaktadır (Satman, 2006: 47).

Liberalizasyon, diğer neo-liberal uygulamaların yanında, ülkenin çok büyük bir kısmında daha yoğun rekabet bulunan ve piyasanın tamamında da faaliyetlerin çoğaldığı bir piyasa modeli ortaya çıkarmıştır. Teknik açıdan piyasaya hâkim olan güçler ve etkin üreticiler meydana gelmiştir. Bütünleşme, bu nedenle liberalizasyonun varsayılan sonuçlarını sağlamamıştır. Piyasaya hâkim olan güçler, yatay-dikey yönlerde bütünleşme sürecine girmişlerdir. Elektrik alanında elektriğin üretimi, dağıtımı, iletimi ve satışı gibi değişik faaliyetler farklı şirketlerin yönetim ve sorumluluğuna verilmiştir. Bu uygulamalar yapılmış olmasına rağmen ilgili faaliyetler umumiyetle bir yerde toplanmış ve aynı kişiler ya da şirketlerce koordine edilmekte veya yürütülmektedir. $\mathrm{Bu}$ sebeple, teferruatlı bir şekilde düzenlenmese de benzer durumlarda satış ve üretim arasındaki ilişki direkt olarak aynı sahiplik içerisinde bir araya gelmektedir. Yatay bütünleşme uygulamalarında ise bölgesel satış ve üretim şirketleri bütünleşmeye başlamıştır. Bu yöntemde yönetim birleşmiştir. Yönetimin birleşmiş olmasına rağmen farklı şirketler, bağımsız üreticiler olarak varlıklarını sürdürmüştür 
(Jacobsen vd., 2006: 3531). Bu yapılanma büyüyen ve yeni piyasalarda liberalizasyon düzenlemelerinden artan tahmin edilen rekabetin gerçekleşmesi yerine, sistemin yapısının sonucu olarak tekelleşme ve kartelleşme eğilimini artırmaktadır (Jacobsen vd., 2006: 3530).

Enerji alanını regüle etmek için, politika oluşturma, kanuni düzenleme, örgütsel ve düzenleyici geliştirme çabası, çok boyutlu ve çift boyutlu kalkınma örgütleri oluşturulmuştur. Özel sektör için enerji alanını ekonomik açıdan çekici bir sektör olarak hazırlamak için sektörün yükselen ekonomik verimliliği teşvik edici bir özellik olarak gösterilmiş ve iki yönlü ekonomik kurumlara Dünya Bankası, IMF ve benzeri örgütler ve bu örgütlerin yanı sıra, çok taraflı borç veren uluslararası kuruluşlar tarafından sınırlayıcı faktörlerle, borç, teknik destek ve bunların dışında mecburiyetler de eklenerek enerji alanındaki modeller oluşturulmuştur. Enerji kıtlığının düşürülmesinin yanı sıra Birleşmiş Milletlerin iddialı amaçları olan Milenyum Kalkınma Hedefleri modeli, elektriğin değerini artırmıştır (Deloitte, 2004: 4). Bu dönemde elektrik piyasası düzenlemelerin merkezine alınarak enerji sektörü bütünleştirilmeye ve yeniden yapılandırılmaya başlanmıştır.

Post-fordist dönemde, enerji piyasası, küresel ölçekte, özenle, sektörün muhtemel piyasa güçlerinin katılımına uygun hale getirilerek liberalleştirilmiştir. Enerji piyasasında, liberalizasyon gerçekleştirmek için yapılan çalışmalar, elektrik piyasasından başlayarak ve elektrik piyasasındaki düzenlemeler esas alınarak gerçekleştirildikten sonra elektrik piyasası büyük ölçüde liberalleştirilen enerji alanındaki ilk sektör olmuş, ancak, elektrik piyasasının yanı sıra doğalgaz, petrol ve elektrik ürünlerinin bütünleşmesi ile bu alt enerji kollarının piyasalarının güçlerinin dikkatle bütünleştirilmesi gerçekleştirilmeye çalış1lmıştır (Jacobsen vd., 2006: 3527). Liberalleşme uygulamaları ile birlikte enerji sektörünün alt kısımları arasında bütünleşme oluşturulmaya başlamıştır. Enerji alanının fayda imkânları ve yeni mülkiyet yapısı regüle edilene kadar, fordist dönemde kâr amacı gütmeyen ilkelere dayanmaktaydı. Regülasyonun yapılmasıyla beraber diğer faaliyetler ve oluşan ağ yapısı yeni regülasyonlarla bütünleştirilerek, değişik özellikte enerji piyasalarının etkinlikleri bütünleştirilmiştir. Liberalizasyon, enerji sektöründe bulunan hedeflerin yanı sıra, büyük bir coğrafi dağılım içinde yoğunluğu artmış rekabete dayanan ve etkinliğin bütün piyasada geliştiği bir piyasa yapısı kurmayı amaç edinmiştir. $\mathrm{Bu}$ dönemde üreticiler etkinliklerini artırmışlar ve bazı güçler teknik bakımdan piyasayı ele geçirmiştir. Bu nedenle, bütünleşme, liberalizasyonun başlangıçta teorik olarak hedeflenen faydasını oluşturamamıştır (Jacobsen vd., 2006: 3530). Bu uygulamaların sonucunda, piyasa hacmi büyümemiş aksine küçülmüş ve ülkede, enerji sektöründe, belirleyici olanlar, bölgesel örgütlenmeler olmaya başlamıştır. 
Türkiye'de özelleştirmenin yasal altyapısı, 24711/1994 tarih ve 4046 sayılı Özelleştirme Yasasının hazırlanacağı sürede olan zaman diliminde hazırlanan 20 civarında (1984-1994 yılları arasında) hukuksal düzenleme ile gerçekleştirilmiştir (Yayman, 2000: 140). Özelleştirme konusunda 1984 senesinde uygulamaya konulan Tasarrufların Teşviki ve Kamu Yatırımlarının Hızlandırılması Hakkında kabul edilen 2983 Sayılı Kanun ile nispeten özelleştirme kabul edilen Gelir Ortaklığı Senedi İhracı uygulaması gerçekleştirilmiştir. İşletme hakkı verilmesi ve kamu mülkiyetinin devri yönünde özelleştirmenin gerçek anlamında çalışmalara, KİT'lerin Özelleştirilmesi Hakkında 1986 senesinde uygulamaya başlanan 3291 Sayılı Kanun'undan sonra başlanabilmiştir. Aynı zamanda 1984 senesinde uygulamaya başlanan 233 sayılı Kamu İktisadi Teşebbüsleri Hakkında Kanun Hükmünde Kararname'de mülkiyetin devrine yönelik ve işletme hakkı verilmesinin sağlanması için bazı düzenlemeler yapılmasına rağmen bahsedilen yetki kullanılmamıştır (Afşar, 1998: 1).

Enerji piyasası Türkiye'de, ilk özelleştirmelerin uygulandığı alanlardan birisidir. 1970'li yıllardan itibaren, Türkiye Elektrik Kurumu (TEK)'in 1312 sayılı kanun ile kurulmasıyla beraber, mahalli idareler ile TEK arasında karmaşık bir yetki ve sorumluluk yapısı ortaya çıkmıştır. 1982 yılında ise elektrik ile ilgili faaliyetler belediyelerden TEK'e aktarılmıştır. 1982 yılında TEK ve DSİ'nin santral kurma tekeli 2705 sayılı kanun ile ortadan kaldırılmış ve devlet haricinde özel sektöre santral kurma hakkı oluşturulmuştur. 2983 sayılı kanun ile de doğrudan özelleştirmeye yönelik ilk düzenleme gerçekleştirilmiştir. 3096 sayılı kanun ile de TEK'in tekel konumu sona ermiştir (Sarı̈ürk, 2009: 144). Enerji sektörü, idari açıdan parçacıllaştırılıp, daha sonra da yeniden yapılandırılarak özelleştirilmişstir. Bunu temin edebilmesine yönelik 1993 senesinde Türkiye Elektrik Kurumu, parçalanarak TEDAŞ ve TEAŞ olmak üzere iki şirkete bölünerek ve bu yöntemle dağıtım firmalarına parçalanan TEDAŞ özelleştirilebilir, başka bir ifade ile satılabilir hale getirilmiştir. 2001 senesinde Dünya Bankası'nın Türkiye'ye temin ettiği kredilere ön şart olarak Elektrik Üretim Anonim Şirketi (EÜAŞ), Türkiye Elektrik İletim Anonim Şirketi (TEİAŞ), Türkiye Elektrik Üretim İletim Anonim Şirketi (TEAŞ) ve Türkiye Elektrik Ticaret ve Taahhüt Şirketi (TETAŞ) olarak üç parçaya ayrılmıştır. Bu uygulamadan sonra sektörün bir bütün halindeki, dikey bütünleşik örgütsel yapısı, sona erdirilerek özelleştirme yapmaya müsait bir yatay konumlanma oluşturulmuştur (Kükey, 2004: 53). 
Enerji piyasasında özelleştirmeler ve liberalizasyon ile birlikte fordist dönemdeki enerji sektörünün, fordist dönem örgütsel biçimi sona ermiştir. Dikey bütünleşik örgütlenme modelinin yerini örgütsel parçalanma ve yatay durumda olan örgütlerin bütünleşmeleri almaya başlamış ve enerji alanının iktisadi yapısı ve işleyişi değişmiştir. Özellikle dağıtım aşamasının yanı sıra üretim aşaması da sermayeye açılmış, piyasanın sermayenin ihtiyaçlarına ve piyasanın devamını sağlamaya yönelik olarak regülasyonun sağlanabilmesi için de EPDK görevlendirilmiştir. EPDK, piyasanın faaliyetlerini yürütmesini Elektrik Piyasası Kanunu, Doğal Gaz Piyasası Kanunu, Petrol Piyasası Kanunu ve Sıvılaştırılmış Petrol Gazları (LPG) Piyasası Kanunları tarafından verilen yetki ve göreve bağlı olarak düzenlemeye ve yönetmeye başlamıştır. Elektrik Piyasası Kanunu'nun verdiği yetkiye dayanarak piyasa şartlarında da köklü değişiklikler ortaya çıkarılırken, enerji sektöründeki kitlerin yapısı ve fonksiyonunun yanında, doğal tekel olan dağıtım bölgelerinin ve kamuya ait üretim tesisleri de özelleştirilmesi esas alınmıştır (TES-İş, 2007: 50). Enerji sektöründeki özelleştirmelerden sonra, enerji sektörünün işleyişi ve mülkiyet yapısı devletin bu sektördeki rolü de yeniden oluş̧turulmuştur.

EPDK, yap1 ve işleyiş olarak kamu yönetiminde esneklik uygulamalarının tipik örneklerindendir. İç ile dış esneklik sınıflarına dair uygulamaların bütününün örneklenebileceği esneklik uygulamaları gerçekleştirilmektedir. Örneğin, dış esneklik uygulama örneklerinden biri olan nicel esneklik tipi özelliğini taşıyan istihdam pozisyonu bunun örneğidir. EPDK'da hizmetler, mali haklar ve ücret haricinde 657 sayılı Devlet Memurları Kanunu'na tabiidir. Sözleşmeli statüde çalışan ama Devlet Memurları Kanunu uygulanan personel çalıştırılmaktadır. Dış nicel esnekliğin gerektirdiği şartlara uygun olarak hem sürekli statüde istihdam edilen personel hem de sözleşmeye dayalı geçici personel istihdam edilmektedir. Kurumda, merkezi konumda ve az sayıda bulunan, kurumun çekirdeği niteliğinde bir devlet memurları istihdamı gerçekleştirilmiştir ve bu kadroda bulunanlar kurumun kültürünü ve hafızasını zamanla oluşturarak taşıyacaktır. Kurumun kendi amaçlarına ulaşabilmek için ise sözleşmeli personel istihdam edilmiştir (Sarıtürk, 2009: 183).

Kurumda, dış nitel esneklik uygulamaları gerçekleştirilmektedir. Enerji dağıtım ihaleleri ve denetimlerde dış nitel esneklik uygulamaları bulunmaktadır. Dış denetim şirketleri aracılığı ile denetim gerçekleştirilmekte, bu özel dış denetim firmalarının eliyle gerçekleştirilen denetim weberyen bürokrasi dönemi kamu bürokrasisinin günlük çalışmasındaki denetim yöntemlerinden birisi değildir. Yeni dönem olan Post-fordist dönem parçacıllaşmış ve esnek özelliklere sahip kamu yönetimi örgütlerinin niteliklerindendir. Başka bir dış nitel esneklik 
örneği ise hizmetin özel sektör şirketlerine ihale yöntemi ile verilmesidir. Enerji alanının örgütsel yapısı olan dikey bütünleşik örgütsel yapısı çözülmüş ve bunun sonucunda enerjinin, özellikle de elektrik enerjisi üretim-iletim-dağıtım yapısı bölünmüş ve parçalanmıştır. Parçalanmanın sonucunda ise sektörde taşeronlaşma ortaya çıkmıştır. Bu taşeronlaşma enerji sektörüne uygun bir taşeronlaşma tipi, özellikle, elektrik enerjisi alanında ortaya çıkmıştır. Elektrik enerjisinde İletim ve dağıtım altyapısı önemli oranda kamu yönetiminin kontrolündedir. Elektrik enerjisi ile ilgili örgütsel yapının parçalanması, devlet mülkiyeti ve kontrolündeki elektrik altyapısı üzerinden iletim ve dağıtım gerçekleştiren özel sektör şirketlerinin ihale yöntemi ile iletim ve dağıtım yaptıkları da göz önünde bulundurulduğunda, bu durum sektörü işlevsel bakımdan taşeronlaştırmaktadır. Özel sektörün mülkiyete sahip olduğu hallerde de enerji alanının dikey bütünleşik örgütsel yapısının dağıtılarak ağ yapısı içinde yeniden oluşması sonucunda sektörün iktisadi yapısı tabiatı gereği taşeron yapılar ortaya çıkmasına neden olacaktır. Kurum, iç esneklik tipi uygulamaları gerçekleştirmektedir. Kurumda çalışma biçimleri ve süreleri esnekleşmektedir. Geçici-finansal esneklik ve değişken zamanlı çalışma yöntemleri ile atipik çalışma zamanları oluşturulmaktadır. Personelin kısa zamanlı çalışmaları esnek istihdam örneklerindendir. Kurum, iç nitel esneklik tipinde uygulamaları da gerçekleştirmektedir (Sarı̈ürk, 2009: 184).

Kurum, esneklik uygulamaları olarak kamu bürokrasisinin örgüt yapısının parçalanmasının tipik örneklerindendir. BİO’lar, serbest piyasa ekonomisinin devamını sağlamaya yönelik olarak devlet tarafından oluşturulan ve kamu gücüne sahip kurumlar olarak özel sektör mantığı ve anlayışı ile faaliyet yürüten örgütlerdir. EPDK'nın oluşturulması da enerji alanında kamu bürokrasisinin yönetim yapısı, işleyişinin odak noktasında EPDK, başka bir ifade ile piyasa bulunacak şekilde yeniden yapılandırılmıştır. Enerji konusunda görev alan bütün diğer kurumlar, Enerji ve Tabii Kaynaklar Bakanlığı (ETKB) da hariç olmamak üzere Kuruma göre konumlandırılarak yeniden yapılandırılmışlardır. Devlet örgütlenmesi içinde ETKB'nın yetki ve sorumlulukları ve konumu EPDK'nın yetki ve sorumlulukları ve konumu merkeze yerleştirilerek belirlenmiş, ETBK bünyesinde bulunan çeşitli statüdeki kurumlar ise çeşitli görevler aracılığı ile EPDK ile bağlantılı hale getirilmişler ve ikili bir yapı ve işleyiş oluşturulmuştur. EPDK hem yargı üzerinde hem de kamu yönetimi üzerinde parçacıllaşmanın ortaya çıkmasında etkili olmuştur. Danıştay, Kurumun piyasaya yönelik işlemleri ile düzenlemeleri konusunda ilk derece yargı mercii görevi verilmiş, bunun sonucu olarak da Kurum, idari yargı sisteminde, birinci dereceden yargı mercii konumu oluşturularak idari 
yarg1 düzeninde de parçacıllaşma oluşturulmuştur. Üst kurulların yasama, yürütme ve yarg1 benzeri yetkilere sahip olmasının yanında bağımsızlık ve özerkliğe sahip olmasının sonucu ve gereği olarak yönettikleri alanlarda çalışmalarını optimal bir sonuca ulaştırmak için devletin gücü ve örgütsel yapısı parçacıl hale getirilmiş; varlığının devamına ve kuruluş amaçlarını varlık nedenlerine uygun olarak yerine getirebilmeleri için yeniden yapılandırılmıştır. Poliarşik sistemlerdeki güçler ayrılığı ilkesinin, siyasal alanın doğrudan kontrolünün dışında oluşturulan BİO'lar ile tekrar piyasa ekonomisi lehine oluşturulması olarak yorumlanabilecek bir kamu yönetimi yapısı kurulmaktadır. Yeni kamu yönetimi yapılanmasının odak noktasında, çok büyük ve geniş alanlarda bağlı yetkiye dayalı olarak faaliyet gerçekleştiren kurumlar, kurullar ve başkanlardan oluşan yeni bir bürokrasi tipi bulunmakta, az sayıda personelden oluşan ve sürekli istihdam edilen çekirdek bir grup ile BİO’lar faaliyetlerini devam etmekte ve esneklik BİO’ların ve onun işleyişinin temel karakteri haline gelmektedir (Sarıtürk, 2009: 184).

\section{SONUÇ}

Devlet, egemen sınıfın egemenlik aracıdır ve ekonomik güce sahip olan ve hâkim olan sınıfın ihtiyaçlarının karşılanmasına yönelik olarak ekonomiyi, kültürü, devletin örgütsel yapısını ve toplumu şekillendirmektedir. Her kriz döneminde, krizden çıkmak için yeni düzenlemeler yapılmakta ve kapitalist sistemin devamı sağlanmaktadır. Kapitalizm doğası gereği dönemsel krizlere girmekte ve her kriz yeni bir birikim rejimi ile aşılmaktadır.

Post-fordist dönemde, rekabet artmış ve sermaye küreselleşmiştir. Kapitalizmin devamını sağlayabilmek için hem devlet hem de sermaye, esnek birikim rejimi ile yeniden yapılandırılmıştır. Post-fordist dönemde merkez ülkelerde bulunan sermaye, uluslararası boyutta yayılmaya başlamış, bu alanda yeni firsatlar ve pazarlar ile yeni rakipler bularak talep yetersizliği problemini önemli ölçüde çözmüş dolayısıyla talep yetersizliği sorununu çözmek için ihtiyaç duyduğu sosyal harcamalara artık gerek kalmamış aynı zamanda rekabet şartları bunu gerektirmiştir. Yeni dönemde ölçek sorunu nedeniyle veya talebi geliştirmek hedefiyle devlet eliyle gerçekleştirilen mali kaynak kullanımına ihtiyaç yoktur.

İktisadî yapıda ortaya çıkan yeni durum, devletin değişimine neden olmuştur. Yeni bir düzenleme dönemi ortaya çıkmış ve devlet esnek ve güçlü bir yapı oluşacak şekilde yeniden düzenlenmiş, piyasanın ihtiyaç duyduğu ekonomik alanları, ihtiyacını karşılaması için piyasaya önemli ölçüde devretmiş bu durumdan sonra da kapitalist sistemin ihtiyaçlarına uygun hale getirecek şekilde yeniden yapılandırmıştır. Yeni yapılanmada devlet, yatay olarak örgütlenmiş, daha yoğun bir güce sahip, daha hızlı ve etkili, siyasal otoritelerin ve gücün 
denetimin zayıfladığı, doğrudan doğruya piyasa ekonomisi için çalışır hale getirilerek tekrar düzenlenmiştir. Devlet, piyasa içinde piyasa kuralları ile çalışmaktadır. Bu nedenle vatandaşı “müşteri” kabul ederek yeni bir bağ kurulmuş, fordist dönemde vatandaşın vatandaş olması nedeniyle ortaya çıkacak sosyal maliyetin ekonomik ve mali sonuçları sermayenin üzerinden alınmış ve hizmet ve mal sunulan her alanın tamamına yakınından, sermaye için yeterince kârlı olmadığından ya da maliyetinin özel sektör için yüksek olmasından dolayı, yürütmeye devam ettiği altyapı hizmetleri istisna olmak üzere, hemen hemen tamamen özel sektöre bırakmış ve bu alanlardan kendisini geri plana almış ve mal ve hizmeti özel sektörle birlikte ve rekabet ederek, piyasada piyasa kurallarına uygun olarak yeniden kurulmuştur. Devlet, yeni konumunda, rekabeti olumsuz yönde etkilemeyen ya da engellemeyen diğer aktörlerle aynı ağırlığa sahip bir piyasa aktörü haline gelmiştir.

Devlet, ekonomik aktör olarak piyasadan önemli ölçüde çekilmesinin yanı sıra, istihdamı esnekleştirerek kamu personelinin statülerini değiştirmiş, sayısını azaltılmış, istihdam büyüklüğü açısından da istihdamı küçültmüştür. $\mathrm{Bu}$ yeni durum, kapitalizm bakımından devletin merkezi rolünü azaltmamış fakat, piyasanın devamını sağlamak için düzenleyici rolünü arttırmıştır. Üst kurullar, esnek birikim rejimi uygulamalarının gerçekleştirildiği dönemdeki devletin temel konumunun tipik örgütsel örnekleridir. Yönetişim yaklaşımını uygulayabilmek için büyük oranda profesyonelizm ve ekonomizm anlayışı taşıyan bir anlayışla tesis edilmişlerdir. Regüle ettikleri sektöre yönelik olarak oluşturulan, sektörü düzenlerken, sosyal devlet döneminde güçlü etkileri bulunan kamu yararı, kamu hizmeti, refah devleti gibi yaygın toplumsal gruplarla ilgili kavramların ikamesini piyasanın gereklerinin ve ihtiyaçlarının aldığı ve piyasanın devamını temin etmeyi sağlamak için faaliyet gösteren kuruluşlardır.

BİO’lar, kanunlarla siyasal denetimin dışında tutulmuşlardır. Ancak çoğunlukla regüle ettikleri alanlar ve sektörlerde politika belirlenme sürecine dahil olmaktadırlar. Bu özellikleri itibariyle siyasal açıdan sorumluluğu olmayan fakat siyasal fonksiyonları da bulunan kurumlara evrilmektedirler. $\mathrm{Bu}$ nedenle, politik sorumluluğu olmadan politik gücü paylaşmaktadırlar.

Üst kurullar, ilk olarak, doğal tekel özelliğindeki iktisadi faaliyet alanlarına yönelik düzenlemelerin sonucunda tesis edilseler de ilerleyen zamanlarda, esnek birikim rejimi ve esneklik uygulamalarının örnek kurumları haline gelmişlerdir. BİO’ların, istihdam biçiminin 
değişmesinde ve kamu yönetiminin parçacıllaşmasında belirleyici etkileri olmuştur. Esnek birikim rejimi aklını temsil eden kurumlar haline gelmişler, devlet örgütlenmesinin yaygın şekli olmaya başlamışlardır. BİO’ların yaygınlaşmasıyla kamu istihdamının hatırı sayılır bir miktarı BİO’lara kaymıştır.

BİO’lar, yürütme ve genel olarak devletten bir hayli özerk, kendi çalışma ve istihdam düzeni açısından esnek fakat bu özelliklerinin sürdürülmesi konusunda katı ve piyasaya ve ekonomik sisteme ise bir hayli bağımlı bir yapıya sahiptir. Yasama, yargı ve yürütme benzeri yetkileri bulunmaktadır ve aynı zamanda ilk derece yargı mercii konumundadır. Üst kurulların denetim sistemi düzensiz hatta belirsizdir. Mali özerklikleri de bulunmaktadır. Devletin BİO'lar üzerlerindeki etkisi oldukça sınırlandırılmıştır. Bağlı yetkiden hareketle örgütün yapısını ve personelini de oluşturabilmektedirler. Bütün çalışmalarını piyasanın devamlılığını sağlamaya ve gerektiği gibi istikrarlı bir şekilde faaliyetlerini yürütmesine yöneltmişlerdir. Yapısal krizleri azaltmaya ve krizlerin etkisini minimum seviyeye indirerek de ekonomik sistemin sürekliliğini sağlamayı hedeflemektedir.

EPDK'nın görevi, enerji piyasasını düzenlemektir. Enerji sektörünün bileşenleri, EPDK içerisinde daire başkanlıkları olarak örgütlenmiştir. Doğal gaz piyasası dağıtımı illerde doğal gaz tekelleri oluşturacak şekilde oluşturulmuştur. Elektrik piyasası bölgesel tekeller oluşturularak dağıtımı gerçekleştirmektedir. Enerji piyasasının düzenlemeleri, kârlılı̆̆ın devamının garanti altına alınmasını ve tam rekabetin yıkıcı etkisinden enerji piyasasını korumayı hedeflemektedir. Enerji ihalelerini kazananlar, hizmeti kendi bölgelerinde tekel niteliğinde yürütmekte ve hizmet süresince geliri garanti altına alınmış bulunmaktadır. 


\section{KAYNAKÇA}

Afşar, H. (1998), “Türkiye'de Özelleştirme ve Özelleştirme Uygulamaları”, Hazine Dergisi, 9.

Akyıldız, H. (2005), “Temel Dinamikleri ve Çelişkileriyle Üretim ve Bölüşüm Süreci”, TÜHIS, Mayis, s.434-453.

Arslan, M. (2017), "Düzenleyici ve Denetleyici Kurum Personelinin Teknotrat Nitelikleri Üzerine Bir İnceleme”, Yüzüncü Yıl Üniversitesi Sosyal Bilimler Enstitüsü Dergisi, 1(Özel Say1-4), s.1-19.

Aslan, O. E. (2005), Kamu Personel Rejimi, Statü Hukukundan Esnekliğe, TODAİE, Yayın No:326, Ankara.

Aydemir, B. (2005), "Stratejik Yönetim ve Bütçe”, 20. Türkiye Maliye Sempozyumu Türkiye'de Yeniden Yapılanma, 23-27 Mayıs, Karahıyat/Pamukkale, s.24-32.

Aydın, M. K. (1999), “Ulusal Kalkınmacılık’tan Küreselleşme’ye”, Bilgi, s.1-23.

Bafra, Kürşad (2011), “Türkiye'de Üst Kurullar ve KHK'larla Yapılan Düzenlemeler”, Toplum ve Hekim, 26(6), s.452-457.

Balkız, Ö. I. (2002), Küreselleşme ve Esnek Üretim Değişen Işs Organizasyonları Üzerine Bir Inceleme, Dokuz eylül Üniversitesi Sosyal Bilimler Enstitüsü, Basılmamış Doktora Tezi, İzmir.

Bayramoğlu, S. (2002), “Küreselleşmenin Yeni Siyasal İktidar Modeli: Yönetişim”, Praksis, 7, s. $85-116$.

Bianculli, A. C., Marín, X. F., Jordana, J. (2013), “The World of Regulatory Agencies: Instituonal Varieties and Administrative Traditions", Jerusalem Papers in Regulation \& Governance, Working Paper No.58. October, s. 1-35.

Casini, L. (2007), "Models of Public Administration: Comparative Analysis of Administrative Organisation",http://unpan1.un.org/intradoc/groups/public/documents/CAIMED/UNP AN028187.pdf, (ET:10.11.2007).

Christensen, J. G., Yeşilkağıt, K. (2005), "Delegation and Specialization in Regulatory Administration: A Comparative Analysis of Denmark, Sweden and The Netherlands", 
Autonomization of State: From Integrated Administrative Models to Single Purpose Organizations, Scancor, Stanford University, April 1-2, s.1-28.

Christensen, T., Lægreid, P. (2005), “Agencification and Regulatory Reforms" "Automization of the State: From Integrated Administrative Models to Single Organizations" Stanford University, April 1-2, s.1-39.

Christensen, T., Lægreid, P. (2007), "Regulatory Agencies- The Challenges of Balancing Agency Autonomy and Political Control”, Governance: An International Journal of Policy, Administration, and Institutions, 20(3), s.499-520.

Christensen, T., Lie, A., Lægreid, P. (2008), "Beyond New Public Management: Agencification and Regulatory Reform in Norway", Financal Accountability \& Management, 24(1), s.15-30.

Deloitte Touche Tohmatsu Emerging Markets Ltd. (2004), Sustainable Power Sector Reform in Emerging Markets-Financial Issues and Options, Submitted to: World Bank, US Agency for International Development (USAID), Final Draft, 18 June.

Eaton, J. (1996), Ekonomi Politik, Üçüncü Baskı, (Çev: Şiar Yalçın), Bilim ve Sosyalizm Yayınları, Ankara.

Egeli, H., Ay, H., Keyifli, N. (2014), "Düzenleyici ve Denetleyici Kurumlar ve Ülke Uygulamaları", Dokuz eylül Üniversitesi İktisadi ve İdari Bilimler Fakültesi Maliye Bölümü, Prof. Dr. Fevzi Devrim'e Armağan, s.209-218.

Ekelund, H. (2007), "Agencification and the EU as a Regulatory State: a Framework fort the Study of European Community Agencies", UACES Student Forum 8th Annual Conference, Nottingham 19th-20th of April 2007.

Ennser-Jedenastik, L. (2016), “The Politicization of Regulatory Agencies: Between Partisan Influence and Formal Independence", Journal of Public Administration Research and Theory, 26(3), s.507-518.

Erdoğan, E., Ak, M. Z. (2003), “Neo-Liberal Ekonomik Dönüşüm ve Sendikalar”, Кamu-İ̧, 7(2), s.1-14.

Erdoğan, G. (2016), “Bağımsız İdari Otoriteler”, TAAD, 7(24), s.565-598. 
Esser, J., Hirsch, J. (1995), Post Fordism, A Reader Edited by Ash Amin, "The Crisis of Fordism and the Dimensions of a 'Post-Fordist' Regional and Urban Structure", Blackwell Publishers, UK Second Edition.

Eyre, S., Heims, E., Koop, C., Lodge, M., Stirton, L., Vibert, F. (2016), "Regulatory Agencies Under Challenge", (Ed: Martin Lodge), Discussion Paper No:81, The London School of Economics and Political Science Centre for Analysis of Risk and Regulation, January, s.1-35.

Farazmand, A. (2002), “Total Quality Management (TQM): Key Concepts and Analysis of Best Practices for Improving Public Service Performance”, International Performance on TQM in Government, 7-9, s.1-25.

Flinders, M. (2004), "Distributed Public Governance in the European Union", Journal of European Public Policy, 11(3), s.520-544.

Fordism and Its Multiple Seguels: The re-Organization of Work in Britain, France, Germany and Japan http://sol.ccsa.ufrn.br/ccsa/docente/wsouza/download/Capital\&Class.doc 14.09.2005.

Frederickson, H. G. (2004), "Whatever Happened to Public Administration? Governance, Governance Everywhere”, Working Paper QU/GOV/3/, s.1-36.

Gouverneur, J. (1997), Kapitalist Ekonominin Temelleri, (Çev: Fikret Başkaya), İmge Kitabevi, Ankara.

Hood, C., James, O., Jones, G., Scott, C., Travers, T. (1988), "Regulation Inside Government: Where New Public Management Meets the Audit Explosion", Public Money \& Management, April-June, s.61-68.

Iliman, Tarık; Tekeli, Recep (2016), “Türkiye'deki Düzenleyici ve Denetleyici Kuruluşlar: İdari Para Cezalarının Hukuksal Zeminlerinin Değerlendirilmesi” Adnan Menderes Üniversitesi Sosyal Bilimler Enstitüsü Dergisi Cilt:3 Sayı:1 s. 23-36.

Jacobsen, Henrik Klinge; Fristrup, Peter; Munksgaard, Jesper (2006), “Integrated Energy Markets and Varying Degrees of Liberalisation: Price Links, Bundled Sales and CHP Production Exemplified by Northern European Experiences” Energy Policy 34. 
James, Oliver (2007), “The UK Central State and Core Executive's Changing Capacity for Coordination and Steering: Stronger but More Limited Tools in the Post - "Whitehall Model" Era of Governance", Study Group on Governance of Public Sector Organizations, EGPA Conference, Madrid 19-22 September, s.1-42.

Jayasuriya, Kanishka (2004), "Neoliberalism, Securitisation and the New Transnational Regulatory Governance”, Working Paper No. 108, Asia Research Center, Murdoch University Perth, Australia, , August 2004, s.1-22.

Jessop, Bob (2002), "Cities and State Restructuring Pathways" Editorial Board of Antipode, ss. $452-472$.

Joint Legislative Audit Committee (2004), "Review of Small Regulatory Agencies", Report No. 04-1, December 2004, Oregon, USA, 1-48.

Jordana, Jacint; Levi-Faur, David; Marin, Xavier Fernández i (2009), Global Diffusion of Regulatory Agencies, Channels of Transfer and Stages of Diffusion, Institut Barcelona D’estudis Internationals, IBEI Working Papers 2009/28, s.1-24.

Kök, S. B. (2006), "Küreselleşme ve Sendikal Hareket, Artan Yoksullaşma”, GOU İIBF İşletme Bölümü, 5. Orta Anadolu İşletmecilik Kongresi, 15-17 Haziran 2006.

Kükey, C. (2004), “Enerjide Özelleştirme ve Yolsuzluk”, Elektrik Mühendisliği Dergisi, 423, s.52-55.

Maggetti, M. (2012), "Regulation in Practice: The de Facto İndependence of Regulatory Agencies", Zurich Open Repository and Archive, University of Zurich Main Library, ZORA URL: https://doi.org/10.5167/uzh-66106, 09.03.2021.

Malyshev, N. (2006), "Regulatory Policy: OECD Experience and Evidence”, Oxford Review of Economic Policy, 22(2), s.274-299.

Marx, K. (1993), 1844 Elyazmaları, İkinci Baskı, (Çev: Kenan Somer), Sol Yayınları, Ankara.

Marx, K. (1997), Kapital, İkinci Cilt, Üçüncü Baskı, (Çev: Alaattin Bilgi), Sol Yayınları, Ankara.

Nölke, A. (2004), "Limits to Democratic Governance: The Case of Transnational Politics", Conference on Democratic Governance, Copenhagen, s. 1-25. 
Nunes, R., Nunes, B. S., and Rego, G. (2015), “A New Governance Model for Independent Regulatory Agencies", Theoretical Economics Letters, 5, s.4-13.

Özer, M. A. (2005), “Günümüzün Yükselen Değeri”, Saylştay Dergisi, 59, s.3-46.

Parker, R. and Bradley, L. (2004), "Bureaucracy or Post-Bureaucracy? Public Sector Organisations in a Changing Context", The Asia Pacific Journal of Public Administration, 26(2), s.197-205.

Phillips, L. and Ilcan, S. (2003), “A 'World Free From Hunger’: Global Imagination, and Governance in the Age of Scientific Management”, Sociologia Ruralis, 43(4), s. 434453.

Politik Ekonomi Ders Kitabı (Çev: İsmail Yarkın), (1992), İnter Yayınları, Ankara.

Sarısu, A. (2011), “İdari Otoritelerin Ortaya Çıkışı ve Temel Özellikleri”, Yaklaşım, 19(222), s.224-229.

Sarıtürk, M. (2009), Kamu Yönetiminde Esneklik ve Bağımsız İdari Otoriteler: Enerji Piyasası Düzenleme Kurumu Örneği, İzmir Dokuz eylül Üniversitesi Sosyal Bilimler Enstitüsü Doktora Tezi.

Satman, A. (2006), "Dünyada Enerji Kaynakları”, Türkiye’de Enerji ve Kalkınma Sempozyumu, Nisan, İstanbul.

Scott, C. (2000), “Accountability in the Regulatory State”, Journal of Law and Society, 27: 38-60 which has been published in final form at http://dx.doi/org/10.1111/14676478.00146. 14.12.2020.

Scott, C. (2003), "Regulation in the Age of Governance: The Rise of the Post-Regulatory State”, National Europe Centre Paper, Australian National University, 100(6), s.1-28.

Şahin, S. (2015), "Bağımsız İdari Otoritelerin Ortaya Çıkış Nedenleri (Reasons for The Emergence of Independent Administrative Authorities)", International Journal of Legal Progress, 1(1), s.14-29, www.intjolep.com. 23.02.2021.

Şaylan, G. (2003), Değişim, Küresellleşme ve Devletin Yeni İşlevi, 2. Baskı, İmge Kitabevi, İstanbul.

TES-İŞ Enerji Araştırmaları Birimi, (2007), "EPDK’ya Eleştirel Bakış", TES-IŞ Dergisi, Ekim, s.44-61. 
Ulusoy, A. (2003), Bă̆ımsız İdari Otoriteler, Turhan Kitabevi, Ankara.

Vielle, P., Walthery, P. (2003), Flexibility and Social Protection, European Foundation fort he Improvement of Living and Working Conditions, Office for Official Publications of the European Communities.

Wallerstein, I. (1996), Tarihsel Kapitalizm, (Çev: Necmiye Alpay), 2. Baskı, Metis Yayınları, İstanbul.

Wettenhall, R. (2005), “Agencies and Non-departmental Public Bodies”, Public Management Review, 7(4), s. 615-635.

Willis, E. M. and King, D. (2011), “Independent Regulatory Agencies and Australia's Health Workforce Crisis", International Journal of Sociology and Social Policy, 31(1/2), s. 21-33.

Yalçın, Ş. (2006), “Dünyada Enerji”, Türkiye’de Enerji ve Kalkınma Sempozyumu, Nisan.

Yayman, H. (2000), “1980 Sonrası Türkiye'de Özelleştirme Uygulamalarının Gelişimi ve Kamu Yönetimi Üzerine Etkileri”, Gazi Üniversitesi İIBF Dergisi, 2(3), s.135-156.

Zubritski, Y., Mitropolski, D., Kerov, V., Kuznetsov, Y., Gretski, V., Lozovski, I. and Kolossov, P. (1995), Kapitalist Toplum, (Çev: Sevim Belli), Sol Yayınları, Ankara.

http://www.epdk.gov.tr/Detay/Icerik/1-1050/kurumsalkurumun-yapisi 10.02.2021.

http://www.epdk.gov.tr/Detay/Icerik/1-1051/kurumsaltarihce 10.02.2021.

http://www.petrol-is.org.tr/2003_CD/18_esneklik/govde.htm 31.03.2004. 